\title{
Holocene Relative Sea-Level Changes from Near-, Intermediate-, and Far-Field Locations
}

\author{
Nicole S. Khan ${ }^{1,2}$ - Erica Ashe ${ }^{2,3} \cdot$ Timothy A. Shaw ${ }^{1,2} \cdot$ Matteo Vacchi ${ }^{4}$. \\ Jennifer Walker $^{1,2}$ - W.R. Peltier ${ }^{5}$ Robert E. Kopp ${ }^{2,6}$ • Benjamin P. Horton ${ }^{1,2,7}$
}

Published online: 12 November 2015

(C) Springer International Publishing AG 2015

\begin{abstract}
Holocene relative sea-level (RSL) records exhibit spatial and temporal variability that arises mainly from the interaction of eustatic (land ice volume and thermal expansion) and isostatic (glacio- and hydro-) factors. We fit RSL histories from near-, intermediate-, and far-field locations with noisy-input Gaussian process models to assess rates of RSL change. Records from near-field regions (e.g., Antarctica, Greenland, Canada, Sweden, and Scotland) reveal a complex pattern of RSL fall from a maximum marine limit due to the net effect of eustatic sea-level rise and glacio-isostatic uplift with rates of RSL fall as great as $-69 \pm 9 \mathrm{~m} / \mathrm{ka}$. Intermediatefield regions (e.g., mid-Atlantic and Pacific coasts of the USA, Netherlands, Southern France, St. Croix) display variable rates of RSL rise from the cumulative effect of eustatic and isostatic factors. Fast rates of RSL rise (up to $10 \pm 1 \mathrm{~m} / \mathrm{ka}$ ) are found in the early Holocene in regions near the center of forebulge collapse. Far-field RSL records exhibit a midHolocene highstand, the timing (between 8 and $4 \mathrm{ka}$ ) and
\end{abstract}

This article is part of the Topical Collection on Sea Level Projections

Electronic supplementary material The online version of this article (doi:10.1007/s40641-015-0029-z) contains supplementary material, which is available to authorized users.

Nicole S. Khan

nkhan@usgs.gov

1 Sea Level Research, Department of Marine and Coastal Sciences, School of Environmental and Biological Sciences, Rutgers University, New Brunswick, NJ 08901, USA

2 Institute of Earth, Ocean, and Atmospheric Sciences, Rutgers University, New Brunswick, NJ 08901, USA

3 Department of Statistics and Biostatistics, and CCICADA (Command, Control, and Interoperability Center for Advanced Data magnitude (between $<1$ and $6 \mathrm{~m}$ ) of which varies among South America, Africa, Asia, and Oceania regions.

Keywords Holocene · Relative sea-level change · Glacio-isostatic adjustment $\cdot$ Noisy-input Gaussian Process model

\section{Introduction}

Reconstructions of Holocene relative sea level (RSL) provide important constraints for calibrating geophysical models of Earth's rheology and glacial-isostatic adjustment (GIA) [1-3], estimating ice-equivalent meltwater input [4-7], and fingerprinting sources of ice mass loss [8-12].

Changes in RSL, which is defined as the height of the ocean surface relative to the land surface or ocean floor [13], are driven by the net effect of eustatic, isostatic (glacio- and
Analysis, A Department of Homeland Security Center of Excellence), Rutgers University, Piscataway, NJ 08854, USA

4 Aix-Marseille Université, CEREGE CNRS-IRD UMR 34, Aix en Provence, France

5 Department of Physics, University of Toronto, Toronto, ON M5S 1A7, Canada

6 Department of Earth and Planetary Sciences and Rutgers Energy Institute, Rutgers University, Piscataway, NJ 08854, USA

7 Earth Observatory of Singapore and Asian School of the Environment, Nanyang Technological University, Nanyang 639798, Singapore 
hydro-), ocean dynamic, tectonic, and local (e.g., tidal regime change or sediment consolidation) factors that act over a variety of spatial and temporal scales $[12,14]$. Since the Last Glacial Maximum (LGM; 26 ka), RSL changes have been driven by the melting of $\sim 50$ million $\mathrm{km}^{3}$ of land-based ice as the Earth transitioned from glacial to interglacial climatic conditions [15-17]. This transfer of mass from land ice to the global ocean both increased ocean volume and triggered a large, ongoing isostatic response of the solid Earth $[4,13$, $18,19]$. The present-day rate of RSL rise due to GIA varies among near-, intermediate, and far-field regions (Fig 1) [20]. In near-field regions (i.e., areas located beneath continental ice sheets at the LGM), the rate of glacio-isostatic uplift during deglaciation exceeded the rate of eustatic (land ice volume and thermal expansion) sea-level rise, resulting in RSL records characterized by continuous RSL fall (Fig 2). Rates of present-day RSL fall as great as $-8 \mathrm{~mm} / \mathrm{a}$ occur in near-field locations (Fig 1). Depression of land beneath LGM ice sheets caused migration of mantle material away from ice load centers, resulting in uplift of a forebulge in intermediate-field regions adjacent to ice sheets [1,21-28]. As land-based ice diminished and mantle material returned to the former load centers, the forebulge collapsed and retreated (glacio-isostatic subsidence). Thus, isostatic and eustatic effects worked in tandem to cause RSL rise. After $7 \mathrm{ka}$, the relative contribution from glacio-isostatic subsidence increased as meltwater input was reduced [4]. RSL rise slowed from the absence of [28] or minimal $[5,7]$ eustatic contribution during the late Holocene (last $4 \mathrm{ka}$ ); RSL rise in these regions resulted from continuing glacio-isostatic subsidence (Fig 2). RSL is rising at present in intermediate-field locations, the rate of which varies with distance to former ice centers (Fig 1). Transitional zones occur at LGM ice-sheet margins (e.g., Massachusetts on the U.S. Atlantic coast) where initial glacio-isostatic uplift was followed by subsidence from forebulge migration [29]. These locations experience rates of present-day RSL rise in the higher

Fig. 1 Current rates of relative sea-level (RSL) change from glacio-isostatic adjustment (GIA) predicted using ICE-6G_C (VM6) model [20]. The color scheme denoting rates of RSL change was chosen to remain consistent with previous GIA modeling studies from the University of Toronto

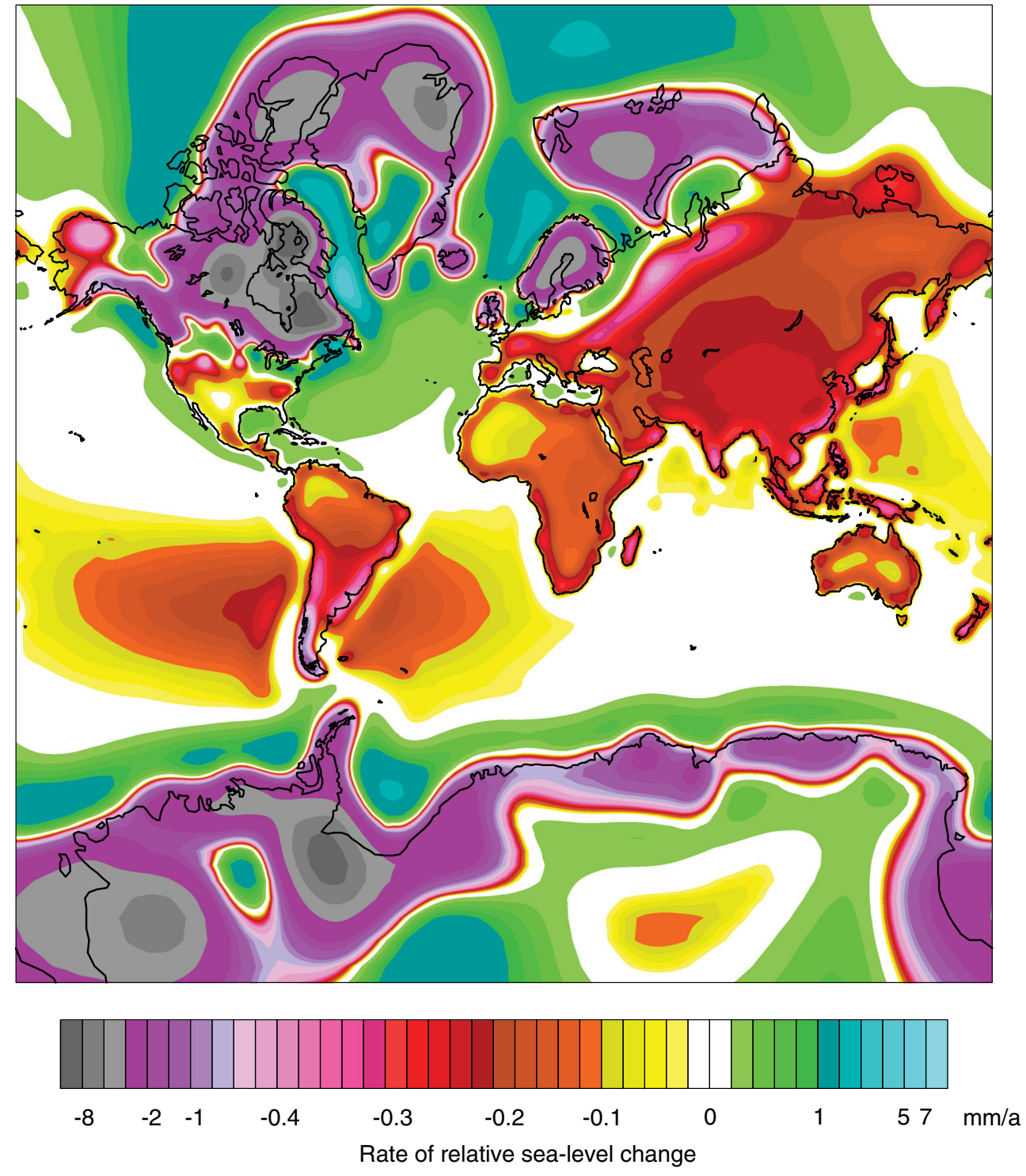


Fig. 2 Schematic representation of the glacio-isostatic adjustment processes in response to the waxing and waning of continental-scale ice sheets and the associated land-level change in near-, intermediate-, and far-field locations modified from Kemp et al. [46]
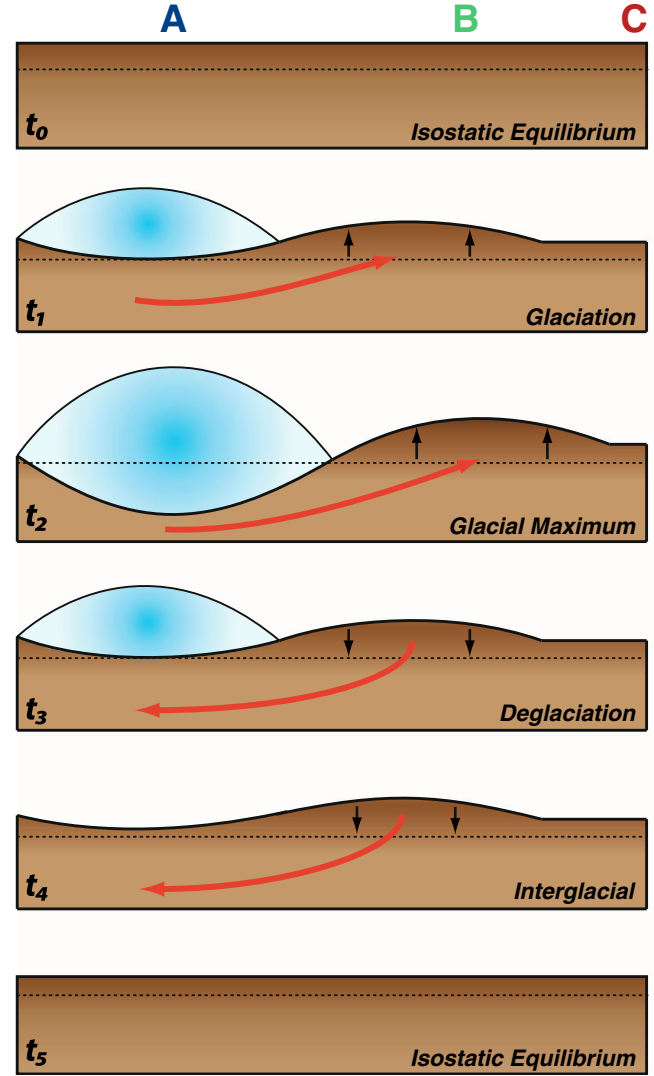

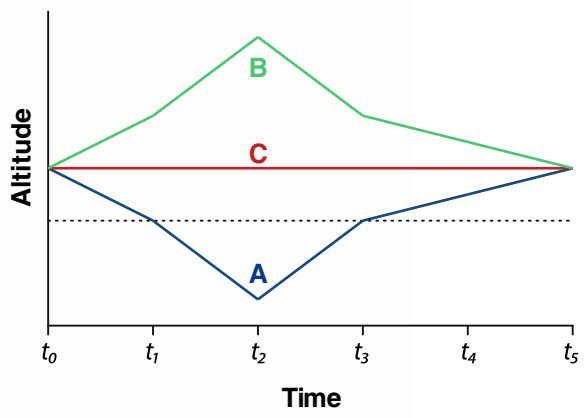

$A=$ near field (e.g. Canada)

$\mathrm{B}=$ intermediate field (e.g. Mid Atlantic, USA) $\mathrm{C}=$ far field (e.g. Brazil)

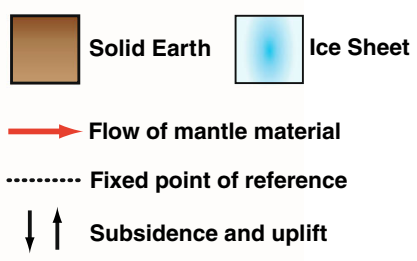

range of intermediate-field sites (Fig 1). In far-field regions at increasing distances from major ice centers, eustatic contributions to RSL change exceeded glacio-isostatic contributions $[4,5,15,16,30-36]$. The RSL signal of many far-field locations is characterized by a mid-Holocene sea-level maximum, or highstand, at the time meltwater production decreased [37]. The fall in RSL to present is due to hydro-isostatic loading (continental levering) [18, 30] and a global fall in the ocean surface due to both hydro- and glacio-isostatic loading of the Earth's surface (equatorial ocean siphoning) [38]. Perturbations to Earth's rotation driven by mass redistribution also cause RSL changes in far-field regions to depart from the eustatic value [39]. These processes occur during the deglacial period but are not manifested in far-field RSL records until the early to mid-Holocene because the eustatic signal is dominant prior to this time [5]. Far-field locations are characterized by present-day rates of RSL change that are near constant or show a slight fall $(<0.3 \mathrm{~mm} / \mathrm{a})$ in RSL (Fig 1).

\section{RSL Histories and Application of Gaussian Process Model}

Here, we present local RSL data that are representative of regional trends to show deglacial patterns of change and identify processes that may have caused these changes. The selected recent and/or benchmark studies illustrate the full range of Holocene RSL variability. Each study has sea-level data from the early to late Holocene and minimal influence from tectonic or local factors (although if the influence from tectonic or local factors is apparent, these factors are discussed in the text). We present studies from a pole-to-pole transect across the Americas (Greenland, North America, the Caribbean, South America and Antarctica) and Eurasia/ Oceania (Europe, the Mediterranean, Asia, Africa, and Oceania) that are representative of the influence of eustatic and isostatic effects on regional RSL histories (Figs. 3, 4). We note that while we have chosen sites representative of regional trends, they do no account for the full variability present in RSL histories within a region.

We show sea-level index points that record the position of RSL over time at each location [40, 41]. Each index point contains information about its (a) geographic location; (b) age from ${ }^{14} \mathrm{C}, \mathrm{U} / \mathrm{Th}$, optically stimulated luminescence or amino acid racemization dating and the associated measurement and/or calibration error; and (c) elevation of former sea level and the associated vertical error. We also show marine and freshwater limiting data that define the lower- and upperbound of RSL, respectively [41]. We do not change the interpretation of index points from the original studies, although in one study [42] where vertical error was not specified for four index points, we assign a conservative $( \pm 1 \mathrm{~m} 2 \sigma)$ error value. 

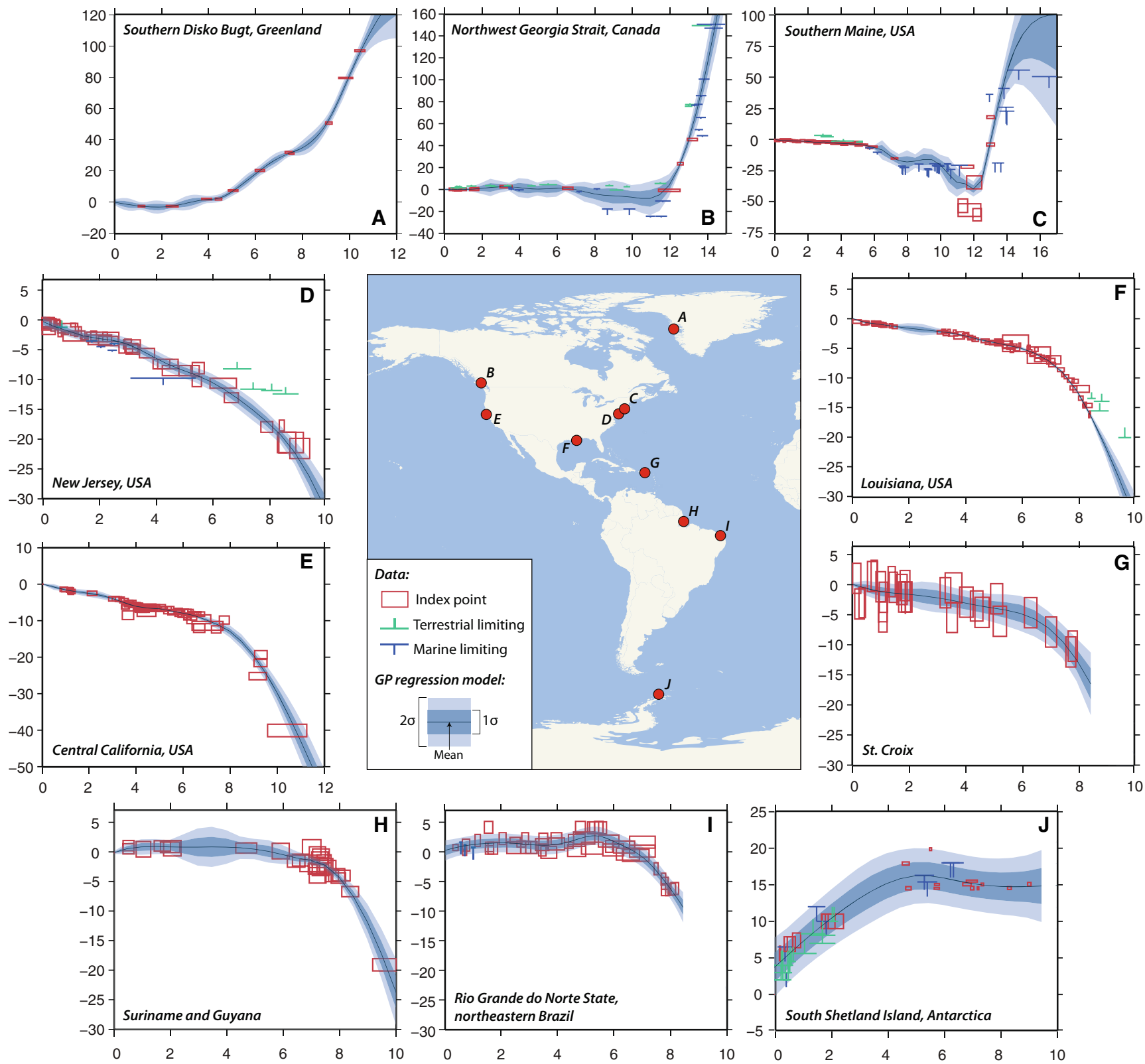

Fig. 3 Selected relative sea-level (RSL) reconstructions from Southern Disko Bugt, Greenland [54, 56], Northwest Georgia Strait, Canada [49], Southern Maine, USA [71], New Jersey, USA [43], Louisiana, USA [74], California, USA [49], St. Croix [99], Suriname and Guyana [100 ], Rio Grande do Norte State, Brazil [102], and South Shetland Islands, Antarctica $[112,114]$. Altitudes and interpretations of sea-level index points (including errors) have not been amended from the original publication

(see section 2 for details). All $y$-axes are RSL (meters to present). Radiocarbon ages were converted to calibrated dates where necessary. $X$-axes are in 1000 calibrated years before present (ka). Limiting points that do not constrain the position of RSL are not shown. Blue curves show the Gaussian process model fit to the data, with the heavily/lightly shaded areas representing $1 \sigma / 2 \sigma$ uncertainties

We acknowledge that the error values of many of the index points may be underestimated, in particular because local factors that influence RSL, such as sediment compaction or tidal range change, are not considered [43]. Where necessary, we have converted radiocarbon ages into thousand calibrated years (ka) before present (BP), where the year 0 BP is conventionally taken to be $1950 \mathrm{CE}$. For clarity, we describe ages to the nearest $0.1 \mathrm{ka}$ without chronological uncertainty. The RSL data can be found in Online Resource 1.
We expand on recent reviews showing Holocene RSL variability [13, 44-47] by applying a non-parametric statistical technique (empirical hierarchical modeling with Gaussian process priors) that appropriately accounts for the vertical and chronological uncertainties of the RSL data to provide a probabilistic assessment of past RSL changes and rates of past RSL change [48-50]. This method has not been previously adopted to describe spatial variability in RSL change on a global scale and represents a 

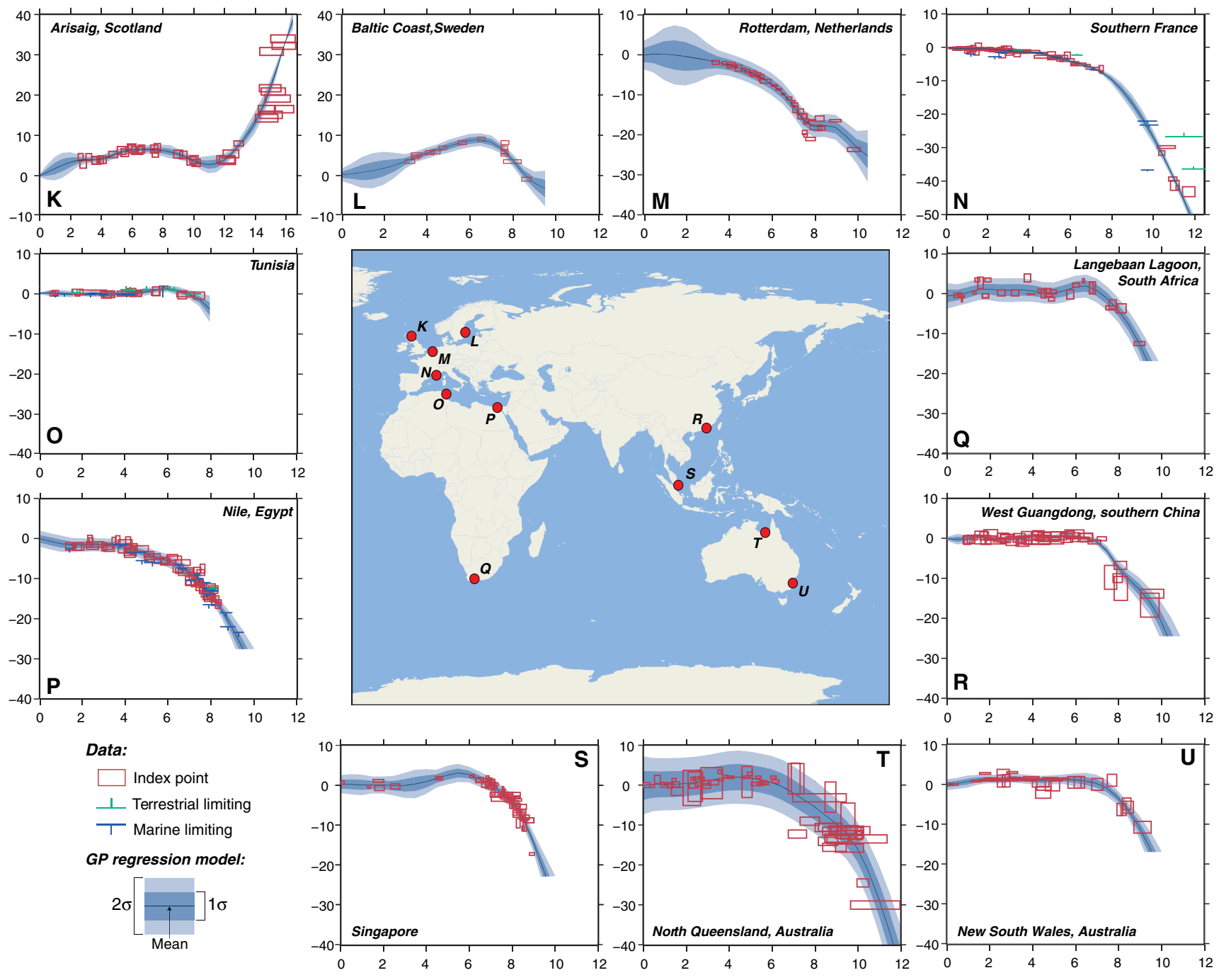

Fig. 4 Selected relative sea-level reconstructions from Arisaig, Scotland [121], Baltic Coast of Sweden [122], Rotterdam, Netherlands [123], Southern France [138], Tunisia [138], Nile, Egypt [141], Langebaan

Lagoon, South Africa [42], West Guongdong, China [166], Singapore [160], and North Queensland, Australia [181], and New South Wales, Australia [182] shown as in Fig. 3

considerable advancement of the approach to determine rates of Holocene RSL change.

We assume that RSL over time at each site, indicated by $f(t)$, can be characterized by a Gaussian process prior [51]. The prior mean is taken as either the maximum or the mean of all of the RSL data at the given site (maximum if near-field and mean if intermediate- or far-field). The prior covariance is given by a Matérn covariance function with smoothness parameter $\nu=3 / 2$ :

$k(\Delta t)=\sigma_{m^{2}}\left(1+\frac{\sqrt{3} \Delta t}{\tau}\right) \exp \left(-\frac{\sqrt{3} \Delta t}{\tau}\right)$,

where $\sigma$ is the prior amplitude of RSL variability, $\tau$ is the characteristic time scale of variability, and $\Delta t$ is the temporal distance between two time points (see Online Resource 2 for further detail). The proxy records provide noisy observations $y_{\mathrm{i}}$ of $f(t)$, with geochronological uncertainty incorporated

using the noisy-input Gaussian process method of McHutchon and Rasmussen [52]:

$y_{i}=f\left(t_{i}+\delta_{i}\right)+\varepsilon_{i}$

$f\left(t_{i}+\delta_{i}\right) \approx f\left(t_{i}\right)+f^{\prime}\left(t_{i}\right) \delta_{i}$

where $t_{i}$ is the mean reported age of observation $y_{i}, \delta_{i}$ is the error in the age estimate, and $\varepsilon_{i}$ is the error in the height estimate. Both age and height errors are assumed to be normally distributed. The variance of the age error is calculated from the error specified in columns 8 and 9 of Online Resource 1 . The variance of the vertical error is calculated from the specified error in columns 5 and 6 , augmented by a constant $\sigma_{n}^{2}$ to correct for underestimation of data errors. The hyperparameters $\sigma_{\mathrm{m}}{ }^{2}, \tau$, and $\sigma_{n}{ }^{2}$ are tuned separately for each site to maximize the marginal likelihood of the model conditional upon the observations at that site. The reported rates of sea-level change are average rates calculated over the 
specified time interval based on a linear transformation of $f(t)$.

In the following sections, we present model predictions and rates using the mean and $1 \sigma$ uncertainty (Figs. 3, 4). We present average rates of RSL change for 1-ka intervals for each of the sites in Table 1 and Fig. 5.

\section{Greenland}

In the near-field location of Greenland, reconstructions from isolation basins provide information on the age of the marine limit of the Greenland Ice Sheet (GrIS) and decimeter-scale changes in RSL since $\sim 15 \mathrm{ka}$ [53-59]. Greenland's RSL history has been dominated by glacio-isostatic uplift from the retreat of the GrIS since the LGM, although spatial variability exists across the region due the variations in local ice load history as well as the influence of the Laurentide deglaciation [60-64].

Isolation basins from Qeqertarsuatsiaq [54] and Innaarsuit [56] located in southern Disko Bugt, west-central Greenland, indicate ice free conditions at $10.5 \mathrm{ka}$, followed by a rapid fall in RSL at a rate of $-29 \pm 2 \mathrm{~m} / \mathrm{ka}$ to $40 \pm 3 \mathrm{~m}$ by $8.5 \mathrm{ka}$ (Figs. $3 \mathrm{a}$, 5a) due to significant, rapid ice retreat, and the associated glacio-isostatic uplift [64]. The rate of RSL fall slowed to $-8.6 \pm 0.7 \mathrm{~m} / \mathrm{ka}$ between 8.5 and $4 \mathrm{ka}$ before RSL reached its present-day level at $4 \mathrm{ka}$. RSL then dropped to a lowstand of $-2.6 \pm 0.2 \mathrm{~m}$ at $\sim 2 \mathrm{ka}$. RSL records across Disko Bugt show broadly similar RSL histories to the Qeqertarsuatsiaq and Innaarsuit record, although the timing of ice margin retreat (northwest of Disko Bugt and Disko Island became ice free before the main bay) and timing of the mid- to late Holocene lowstand ( $\sim 3 \mathrm{ka}$ in the east and $\sim 2 \mathrm{ka}$ in the west) varies,

Table 1 Average rates $(\mathrm{m} / \mathrm{ka})$ of RSL change for each site. Values listed are mean \pm 1 standard deviation

\begin{tabular}{|c|c|c|c|c|c|c|c|c|c|c|c|c|c|c|c|c|c|c|}
\hline \multicolumn{19}{|l|}{ Average rate (m/ka) } \\
\hline Site & \multicolumn{3}{|c|}{$12-10 \mathrm{ka}$} & \multicolumn{3}{|c|}{$10-8 \mathrm{ka}$} & \multicolumn{3}{|c|}{$8-6 \mathrm{ka}$} & \multicolumn{3}{|c|}{$6-4 \mathrm{ka}$} & \multicolumn{3}{|c|}{$4-2 \mathrm{ka}$} & \multicolumn{3}{|c|}{$2-0 \mathrm{ka}$} \\
\hline \multicolumn{19}{|l|}{ Greenland } \\
\hline Southern Disko Bugt, Greenland & & & & -23 & \pm & 2 & -8.4 & \pm & 1.5 & -8.1 & \pm & 1.1 & -2.4 & \pm & 1.2 & 1.6 & \pm & 1.0 \\
\hline \multicolumn{19}{|l|}{ North America } \\
\hline Southern Maine, USA & 9.6 & \pm & 2.8 & 1.4 & \pm & 3.1 & 5.8 & \pm & 2.4 & 1.5 & \pm & 0.6 & 0.8 & \pm & 0.3 & 0.7 & \pm & 0.2 \\
\hline Northwest Georgia Strait, Canada & -6.0 & \pm & 3.3 & 1.5 & \pm & 3.4 & 2.6 & \pm & 3.3 & 0.2 & \pm & 3.1 & -0.3 & \pm & 2.9 & -0.5 & \pm & 1.4 \\
\hline New Jersey, USA & & & & 7.2 & \pm & 1.2 & 3.4 & \pm & 0.5 & 2.0 & \pm & 0.5 & 1.6 & \pm & 0.4 & 1.4 & \pm & 0.4 \\
\hline Central California, USA & 14 & \pm & 1 & 8.6 & \pm & 1.0 & 2.6 & \pm & 0.4 & 0.9 & \pm & 0.2 & 1.8 & \pm & 0.3 & 1.3 & \pm & 0.3 \\
\hline Louisiana, USA & & & & & & & 3.7 & \pm & 0.1 & 1.1 & \pm & 0.1 & 0.6 & \pm & 0.2 & 0.8 & \pm & 0.2 \\
\hline \multicolumn{19}{|l|}{ Caribbean and South America } \\
\hline St. Croix & & & & & & & 4.0 & \pm & 1.2 & 0.9 & \pm & 0.9 & 0.7 & \pm & 0.7 & 0.8 & \pm & 0.5 \\
\hline Suriname and Guayana & & & & 9.9 & \pm & 1.4 & 2.0 & \pm & 0.5 & 0.7 & \pm & 0.9 & 0.0 & \pm & 0.7 & -0.5 & \pm & 0.4 \\
\hline Rio Grande do Norte State, Brazil & & & & & & & 4.0 & \pm & 0.6 & -0.2 & \pm & 0.6 & 0.1 & \pm & 0.6 & -0.7 & \pm & 0.4 \\
\hline \multicolumn{19}{|l|}{ Antarctica } \\
\hline South Shetland Island, Antarctica & & & & & & & 0.6 & \pm & 1.4 & -0.4 & \pm & 1.4 & -2.4 & \pm & 1.4 & -5.2 & \pm & 1.0 \\
\hline \multicolumn{19}{|l|}{ Northwest Europe } \\
\hline Arisaig, Scotland & -0.1 & \pm & 0.5 & 1.3 & \pm & 0.5 & 0.1 & \pm & 0.5 & -1.2 & \pm & 0.4 & -0.4 & \pm & 0.7 & -1.6 & \pm & 0.6 \\
\hline Baltic coast Sweden & & & & & & & 2.7 & \pm & 0.6 & -1.6 & \pm & 0.6 & -2.0 & \pm & 1.1 & -0.8 & \pm & 1.0 \\
\hline Rotterdam, Netherlands & & & & 2.6 & \pm & 1.3 & 5.3 & \pm & 1.0 & 2.5 & \pm & 1.0 & 0.9 & \pm & 2.0 & 0.4 & \pm & 1.9 \\
\hline \multicolumn{19}{|l|}{ Mediterranean } \\
\hline Southern France & 13 & \pm & 1 & 8.6 & \pm & 0.5 & 2.8 & \pm & 0.4 & 1.4 & \pm & 0.2 & 0.5 & \pm & 0.1 & 0.2 & \pm & 0.1 \\
\hline Tunisia & & & & & & & 2.7 & \pm & 0.9 & -0.6 & \pm & 0.3 & -0.1 & \pm & 0.3 & 0.1 & \pm & 0.2 \\
\hline Nile, Egypt & & & & 9.8 & \pm & 1.5 & 4.3 & \pm & 0.6 & 1.7 & \pm & 0.6 & 0.3 & \pm & 0.6 & 0.8 & \pm & 0.7 \\
\hline \multicolumn{19}{|l|}{ Africa } \\
\hline Langebaan Lagoon, South Africa & & & & 11 & \pm & 2 & 3.1 & \pm & 1.1 & -0.5 & \pm & 1.0 & 0.2 & \pm & 1.0 & -0.6 & \pm & 0.7 \\
\hline \multicolumn{19}{|l|}{ Asia } \\
\hline West Guangdong, China & & & & 6.8 & \pm & 1.3 & 4.0 & \pm & 0.4 & 0.1 & \pm & 0.3 & -0.2 & \pm & 0.2 & -0.1 & \pm & 0.2 \\
\hline Singapore & & & & 13 & \pm & 2 & 3.3 & \pm & 0.7 & -0.8 & \pm & 0.9 & -0.5 & \pm & 0.9 & 0.0 & \pm & 0.5 \\
\hline \multicolumn{19}{|l|}{ Oceania } \\
\hline North Queensland, Australia & 16 & \pm & 3 & 5.3 & \pm & 2.4 & 3.1 & \pm & 2.4 & 0.6 & \pm & 2.4 & -0.8 & \pm & 2.4 & -0.2 & \pm & 1.6 \\
\hline New South Wales, Australia & & & & 9.5 & \pm & 1.6 & 2.3 & \pm & 0.6 & 0.0 & \pm & 0.5 & 0.1 & \pm & 0.4 & -0.7 & \pm & 0.3 \\
\hline
\end{tabular}



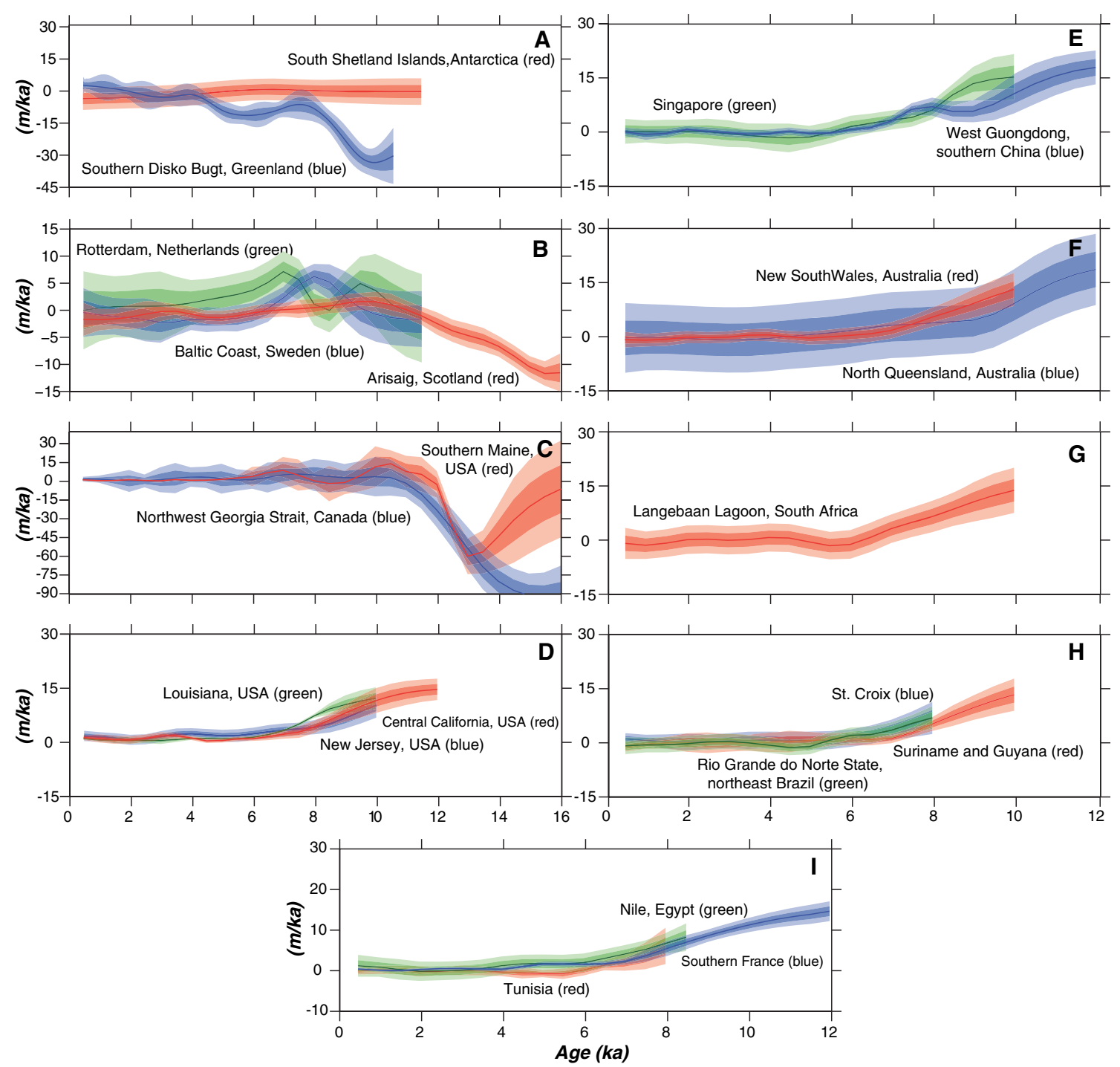

Fig. 5 1-ka average rates of RSL change calculated from the Gaussian process model from each site presented in Figs. 3 and 4 in the following regions: Antarctica/Greenland (a), Europe (b), North America (c, d), Asia

(e), Oceania (f), Africa (g), Caribbean/South America (h), Mediterranean (i). Heavily/lightly shaded areas represent $1 \sigma / 2 \sigma$ uncertainties

which is consistent with the progressive expansion of a belt of forebulge subsidence from ice sheet regrowth during the neoglacial $[53,64,65]$.

On a broader scale, other Greenland sectors show a different pattern in RSL change. Sites in southern Greenland (e.g., Paamiut [59], Nanortalik [61, 62], Qaqortoq [62], Tasiusaq [66]) became ice free at $\sim 15 \mathrm{ka}$, after which RSL fell rapidly until it reached its present level at $\sim 10 \mathrm{ka}$ and prior to $4 \mathrm{ka}$ fell to a lower lowstand compared to western Greenland of -6 to $-8 \mathrm{~m}$. Ammassalik, southeast Greenland [67], shows the characteristic "J-shaped" form in its RSL history observed in western Greenland, although displays a rapid fall in RSL in the early Holocene more similar to southern Greenland records [64, 67], which suggests fast removal of a large volume of ice during initial ice margin retreat in these areas [62, 64, 67]. Such RSL spatial variability reflects the complex interplay among the GIA response to retreat and advance of the GrIS, glacio-isostatic subsidence from collapse of the Laurentide ice sheet (LIS) proglacial forebulge, and eustatic sea-level rise.

\section{North America}

\section{Atlantic Coast}

Near- and intermediate-field sites along the North American Atlantic coast exhibit spatially variable RSL histories due to deglaciation of the LIS and movement towards isostatic equilibrium $[68,69]$. RSL histories of once-glaciated, near-field regions from Canada to Long Island have been driven by GIA 
and eustatic sea-level changes. Glacio-isostatic uplift caused RSL fall in Newfoundland and Labrador (from a maximum of $120 \mathrm{~m}$ at $16 \mathrm{ka}$ ) since the LGM [70]. Nova Scotia experienced a RSL lowstand of $-65 \mathrm{~m}$ at $13.5 \mathrm{ka}$ and then rose at decreasing rates through the Holocene [70]. The record from Maine [71] shows retreat of the LIS around $15 \mathrm{ka}$ with a marine limit $>50 \mathrm{~m}$ (Fig. 3c). RSL fell rapidly at a rate of $-47 \pm 9 \mathrm{~m} / \mathrm{ka}$ to a lowstand of $-60 \mathrm{~m}$ at $12.5 \mathrm{ka}$ due to glacio-isostatic uplift [71]. RSL then rose quickly to $-20 \mathrm{~m}$ as early as $10.5 \mathrm{ka}$ before reaching a period of slowly rising RSL from -17 to $-22 \mathrm{~m}$ that lasted until $7.5 \mathrm{ka}$. A switch from glacio-isostatic uplift to subsidence occurred at this time and RSL rose at a relatively constant rate of $2.0 \pm 0.3 \mathrm{~m} / \mathrm{ka}$ from $6 \mathrm{ka}$ to present (Fig. 5c).

Located near the former LIS margin, mid-Atlantic regions from New Jersey to Virginia show monotonic rise in RSL with some of the highest rates of deglacial RSL rise due to the collapse of the forebulge and the associated glacio-isostatic subsidence [68]. Horton et al. [43] accounted for local factors impacting RSL (tidal range change and sediment compaction) to reduce scatter in the Holocene record from New Jersey (Fig. 3d). Using the model of Hill et al. [72], they estimated paleotidal range from $10 \mathrm{ka}$ to present in New Jersey and predicted large Holocene paleotidal changes from 9 to $8 \mathrm{ka}$. Sediment compaction explained meter-scale variations in RSL where intercalated index points were corrected using the thickness of sediment overburden. New Jersey RSL rose rapidly in the early Holocene at an average rate of $4.4 \pm 0.6 \mathrm{~m} / \mathrm{ka}$ from 9 to $7 \mathrm{ka}$, slowing in the mid-Holocene to a rate of $2.4 \pm$ 0.2 from 7 to $3 \mathrm{ka}$. The rate of RSL rise slowed further in the late Holocene to a rate of $1.3 \pm 0.1 \mathrm{~m} / \mathrm{ka}$ from $3 \mathrm{ka}$ to present (Fig. 5d).

South of North Carolina into the U.S. Gulf coast, the effects of GIA diminish [68]. A RSL record derived from compaction-free basal peats demonstrated that Louisiana experienced RSL rise from $8.2 \mathrm{ka}$ to present (Fig. 3f). Following the rapid drainage of proglacial Lake Agassiz, combined with eustatic sea-level rise, high rates of RSL are observed in the early Holocene from 9 to $7 \mathrm{ka}(7.2 \pm 0.4 \mathrm{~m} / \mathrm{ka}$; Fig. 5d) [69, 73, 74]. RSL rise was relatively constant throughout the mid- to late Holocene with a rate of $0.8 \pm 0.0 \mathrm{~m} / \mathrm{ka}$ from $6 \mathrm{ka}$ to present. The data does not support RSL in this region being above present at any time during the Holocene [68, 74].

\section{Pacific Coast}

The Pacific coast of North America includes near- and intermediate-field regions [49]). Deglacial RSL histories of the Pacific coast [75-85] are supplemented by studies of the earthquake and tsunami history of the Cascadia subduction zone along the coasts of British Columbia, Washington, Oregon, and northern California [86-93].
Regions formerly covered by the Cordilleran ice sheet (southern Alaska to Puget Sound, Washington) are strongly influenced by local ice loading, which results in variable RSL histories [85]. In northwest Georgia Strait, RSL fell from a marine limit as much as $154 \mathrm{~m}$ at $14 \mathrm{ka}$ to a lowstand of $>-25 \mathrm{~m}$ at $11 \mathrm{ka}$ after deglaciation due to glacio-isostatic uplift. The rate of RSL fall was as extreme as $-69 \pm 9 \mathrm{~m} / \mathrm{ka}$ (from 10 to $9 \mathrm{ka}$ ) (Figs. 3b, 5c). A small RSL highstand $<5 \mathrm{~m}$ was reached at $5.5 \mathrm{ka}$, followed by a slow rate of RSL fall of $-0.4 \pm 1.2 \mathrm{~m} / \mathrm{ka}$ during the late Holocene from $4 \mathrm{ka}$ to present. The magnitude of the mid-Holocene highstand varies among regions formerly covered by the Cordilleran ice sheet with highstands considerably lower $(\sim 1.3 \mathrm{~m})$ in central Alaska than in much of southern Alaska and British Columbia (up to $7.2 \mathrm{~m}$ ), likely due to the influence of tectonics [94].

Sites south of the Cordilleran ice margin (southern Washington, Oregon, and central California, USA) demonstrate a continuous rise of RSL throughout the Holocene due to collapse of the forebulge and the associated glacio-isostatic subsidence. In central California, RSL rose rapidly in the early Holocene $(10 \pm 1 \mathrm{~m} / \mathrm{ka}$ between 11 and $8 \mathrm{ka})$ before slowing to $1.4 \pm 0.1 \mathrm{~m} / \mathrm{ka}$ in the mid- to late Holocene (7 ka to present) (Figs. 3e, 5d). This rate is of similar magnitude to those observed at intermediate-field sites on the U.S. Atlantic coast [68] and the UK and Fennoscandia [95, 96] (Fig. 5), although a portion of this RSL rise may be attributed to Cascadia subduction zone deformation.

\section{Caribbean and South America}

The Caribbean and South American Atlantic coast represent intermediate- and far-field regions. Early studies of the Caribbean island of Barbados focused on estimating the deglacial eustatic signal [97], although subsequent investigations indicate the Caribbean and South America are influenced by GIA processes, such as glacio-isostatic subsidence, rotational effects, ocean siphoning, and continental levering [3, 5, 36, 98, 99]. The tectonic setting of the Caribbean and South America may also impact RSL records [98]. For example, Austermann et al. [6] found strong perturbation of RSL model predictions due to a high-viscosity slab associated with subduction of the South American Plate beneath the Caribbean Plate, which suppresses local deformation and decreases subsidence.

Records from Caribbean islands such as St. Croix [99] (Fig. 3g) show a monotonic rise in RSL with relatively high rates of $3.9 \pm 1.2 \mathrm{~m} / \mathrm{ka}$ between 8 and $6 \mathrm{ka}$ (Fig. $5 \mathrm{~h}$ ), which Milne et al. [5] attribute to eustatic contributions. The rate of RSL rise slowed in the mid- to late Holocene to $0.8 \pm 0.2 \mathrm{~m} / \mathrm{ka}$ between $6 \mathrm{ka}$ and present. The absence of a highstand in St. Croix is attributed to glacio-isostatic subsidence from LIS forebulge collapse [5, 99]. 
Moving south to Suriname and Guyana [100] (Fig. 3h), a small $(<1 \mathrm{~m})$ highstand emerges at $\sim 7.5 \mathrm{ka}$. Faster rates of RSL rise are found in the early Holocene $(5.2 \pm 0.8 \mathrm{~m} / \mathrm{ka}$ from 9 to $7 \mathrm{ka})$ compared to the mid-Holocene $(1.0 \pm 0.5 \mathrm{~m} / \mathrm{ka}$ from 7 to $5 \mathrm{ka} ; 0.1 \pm 0.4 \mathrm{~m} / \mathrm{ka}$ from 5 to $2 \mathrm{ka}$ ) before RSL fall to present $(-0.5 \pm 0.4 \mathrm{~m} / \mathrm{ka}$ from $2 \mathrm{ka}$ to present) (Fig. 5h). Because Suriname and Guyana are located beyond the southern limit of LIS forebulge collapse, hydro-isostatic loading of the shelf becomes the dominant process and causes uplift of the continent to produce a highstand in the mid- to late Holocene [5].

Rio Grande do Norte State in northeast Brazil shows a similar form in RSL to Suriname and Guyana, and although the timing of the initiation of the highstand is comparable, the magnitude of the highstand at Rio Grande do Norte State is greater at $2.9 \pm 0.6 \mathrm{~m}$ [101, 102]. From $5 \mathrm{ka}$ to present, RSL fell at a rate of $-0.3 \pm 0.4 \mathrm{~m} / \mathrm{ka}$ (Figs. 3i, 5h). Angulo et al. [103] indicated the magnitude of the highstand varied from 2 to $5 \mathrm{~m}$ above present along the Brazilian coastline.

Further south, Rostami et al. [98] showed a highstand of 6 to $7 \mathrm{~m}$ at $\sim 7$ to $8 \mathrm{ka}$ at sites along the Patagonian coast. Rostami et al. [98] suggested that the influence of the Patagonian ice sheet on the RSL data is negligible. The Beagle Channel shows a similar magnitude 6-m highstand, but this highstand occurs at $\sim 6 \mathrm{ka}[104,105]$. The presence of a highstand of the observed magnitude in southern Argentina may be related to local hydro-isostatic loading of the broad continental shelf or proximity to the subduction zone on the Chilean trench $[5,98]$.

\section{Antarctic Peninsula}

RSL data from Antarctica can constrain its ice sheet history [106-109] in this near-field region where large glacio-isostatic gradients occur [110]. The studies that exist from the Antarctic continent show RSL falling from an early Holocene marine limit of $\sim 20 \mathrm{~m}$ in the Antarctic Peninsula, $\sim 40 \mathrm{~m}$ in East Antarctica, and $\sim 30 \mathrm{~m}$ in Ross Ice Shelf [107, 109].

The most recent RSL studies are from the South Shetland Islands of the Antarctic Peninsula [107, 108, 111]. Watcham et al. [112] used radiocarbon dating of isolation basins and beach ridges from the Fildes Peninsula to reconstruct $\mathrm{RSL}$. To overcome the large uncertainties that exist in the ${ }^{14} \mathrm{C}$ reservoir age [113], Simms et al. [114, 115] used optically stimulated luminescence dating of beach ridges in Maxwell Bay to constrain former sea level. These studies show RSL in the South Shetland Islands remained stable between 15 and $16 \mathrm{~m}$ above present from 9.0 to $5.5 \mathrm{ka}$, although there is scatter and large uncertainties in the mid-Holocene data (Fig. 3j). RSL fell from the mid-Holocene to the present level at $-3.2 \pm 1.0 \mathrm{~m} / \mathrm{ka}$ from $3 \mathrm{ka}$ to present (Fig. 5a).

\section{Europe}

Trends of RSL from near- and intermediate-field sites in Europe are characterized by glacio-isostatic uplift (e.g., Scotland and Sweden) and subsidence (e.g., the Netherlands and Germany) in response to melting of the British and Fennoscandian ice sheets since the LGM [1, 96, 116-120]. Despite its relatively small size, the British ice sheet created large variations in RSL trends from the north to south of the UK [95].

Sea-level index points from isolation basins of Arisaig, northwest Scotland [121], where LGM ice thickness was $\sim 900 \mathrm{~m}$, show RSL fall from 40 to $36 \mathrm{~m}$ at $\sim 16 \mathrm{ka}$ to $\sim 3 \mathrm{~m}$ above present at $11 \mathrm{ka}$ (Fig. 4a). Fast rates of RSL fall $(-4.6 \pm$ $0.8 \mathrm{~m} / \mathrm{ka}$ ) occurred between 14 and $12 \mathrm{ka}$ (Fig. 5b), after which RSL rose to a mid-Holocene highstand at $6.6 \mathrm{ka} \mathrm{(6.5}$ $\pm 0.5 \mathrm{~m})$. RSL fell from this highstand with rates not exceeding $-1.6 \pm 1.1 \mathrm{~m} / \mathrm{ka}$ during the late Holocene in response to a reduction in glacio-isostatic uplift and eustatic input [95].

RSL trends from the southern coast of Sweden reveal evidence for rapid sea-level rise following the retreat of the Scandinavian Ice Sheet [122]. Sea-level index points from isolation basins reveal relatively high rates of RSL rise during the early to mid-Holocene with rates of $4.2 \pm 0.6 \mathrm{~m} / \mathrm{ka}$ from 8.5 to $6.5 \mathrm{ka}$ (Fig. $5 \mathrm{~b}$ ) to a highstand of $8.9 \pm 0.5 \mathrm{~m}$ (Fig. $4 \mathrm{~b}$ ). From $6.5 \mathrm{ka}$, the gradual fall in RSL reflects the slow continued glacio-isostatic uplift coupled with minimal eustatic input [122] and is reflected by rates of RSL fall of $-1.4 \pm 0.4 \mathrm{~m} / \mathrm{ka}$ from $5 \mathrm{ka}$ to present.

Hijma and Cohen [123] produced a Holocene RSL record from Rotterdam, Netherlands using basal peats (Fig. 4c). RSL rose rapidly in the early Holocene at a rate of $5.3 \pm 0.9 \mathrm{~m} / \mathrm{ka}$ from 8 to $6 \mathrm{ka}$ (Fig. 5b). This rapid rise included a 2.1 $\pm 0.9-\mathrm{m}$ sea-level jump occurring within 200 years commencing at $8.5 \mathrm{ka}$. The observed trends were attributed to meltwater release from proglacial Lakes Agassiz and Ojibway through the Hudson Strait into the North Atlantic [123]. During the mid to late Holocene, there was a gradual decline in the rate of RSL rise to $1.2 \pm 0.4 \mathrm{~m} / \mathrm{ka}$.

\section{Mediterranean}

The microtidal regime and presence of numerous remains of coastal archeological structures have made the intermediateto far-field Mediterranean region a focus for sea-level studies [34, 124, 125]. Regional compilations of RSL data have been produced for both the eastern [126-128] and western [129-131] Mediterranean coast. Due to its complex tectonic setting [132], RSL histories in the eastern Mediterranean were influenced by the Holocene activity of major faults [126, 133, 134]. In this region, RSL rise slowed significantly in the last $7.5 \mathrm{ka}$, with consequent initiation of deltaic progradations of 
the largest Mediterranean rivers [135] such as the Nile delta $[136,137]$.

RSL records from tectonically stable sectors of the western Mediterranean document a continuous rise from $-45.9 \pm 0.8 \mathrm{~m}$ at $11.5 \mathrm{ka}$ due primarily to glacio- and hydro-isostatic factors [138]. In southern France, RSL rose at $11.5 \pm 0.9 \mathrm{~m} / \mathrm{ka}$ in the early Holocene between 11.5 and 9.5 ka with rates decreasing significantly at $\sim 7.5 \mathrm{ka}$ when RSL reached $-7.4 \pm$ $0.3 \mathrm{~m}$. RSL in the mid-Holocene ( 7.5 to $4 \mathrm{ka}$ ) rose at $1.7 \pm$ $0.1 \mathrm{~m} / \mathrm{ka}$, slowing further in the late Holocene to a rate of 0.4 $\pm 0.1 \mathrm{~m} / \mathrm{ka}$ (Figs. 4d, 5i).

The Southern Tunisia RSL record is characterized by a well-documented mid-Holocene highstand beginning at $7.5 \mathrm{ka}$ (Fig. 4e) [139]. RSL reached a maximum highstand of $1.1 \pm 0.2 \mathrm{~m}$ at $\sim 5.8 \mathrm{ka}$, with RSL falling to present slowly at rate of $-0.19 \pm 0.07 \mathrm{~m} / \mathrm{ka}$ (Fig. $5 \mathrm{i}$ ) from $6.5 \mathrm{ka}$ to present. According to Mauz et al. [140], the Tunisian highstand is compatible with the melting history of the Antarctic ice sheet.

RSL in the Nile, Egypt during the early Holocene rises relatively rapidly from $\sim-23 \mathrm{~m}$ at $9 \mathrm{ka}$ to $\sim-6 \mathrm{~m}$ at $6 \mathrm{ka}$ at a rate of $5.6 \pm 0.6 \mathrm{~m} / \mathrm{ka}$ (Figs. 4f, $5 \mathrm{i}$ ). These rates slowed at $\sim 6 \mathrm{ka}$ with RSL remaining stable in the late Holocene with a rate of rise of $1.0 \pm 0.3 \mathrm{~m} / \mathrm{ka}$ between 6 and $2 \mathrm{ka}$. Recently, Marriner et al. [141] demonstrated that subsidence was a dominant process, especially in the last $\sim 4.0 \mathrm{ka}$, and significantly impacted the late Holocene sea-level history of the Nile delta.

\section{Africa}

In the far-field location of mainland southeastern Africa (e.g., South Africa, Zanzibar, Mozambique), uncertainties exist regarding the timing and amplitude of a mid-Holocene highstand $[42,142-144]$ caused primarily by continental levering [39]. Part of these uncertainties results from the large distances between field sites (e.g., South Africa to Mozambique) and the varied RSL reconstruction methods used [145]. At sites on the mainland of southeast Africa, RSL reached $\sim 2.5$ to $3.5 \mathrm{~m}$ above present by $6 \mathrm{ka}$ [144]. Stable islands off the coast of southern Africa (Mauritius, Reunion and Mayotte) record no highstand (with RSL stabilizing at present level by $3 \mathrm{ka}$ ) because these small atoll islands subside with the ocean floor from hydro-isostatic loading [44, 146, 147]. A recent study of late Holocene RSL in the Seychelles [148], a location demonstrated to closely measure eustatic sea level [39], showed RSL rising $<2 \mathrm{~m}$ in the last $2 \mathrm{ka}$.

In South Africa, Compton [44] studied Langebaan Lagoon, a salt-marsh lagoon on the southwest coast to produce a 9000year Holocene RSL record, which is in general agreement with a previous study of beach rock by Ramsay [149]. In Langebaan Lagoon, RSL rose in the early Holocene at a rate of $4.2 \pm 0.8 \mathrm{~m} / \mathrm{ka}$ between 9 and $6 \mathrm{ka}$ (Figs. $4 \mathrm{~g}, 5 \mathrm{~g}$ ). It reached its present level by $\sim 7 \mathrm{ka}$, rising to a maximum of $3.1 \pm 0.5 \mathrm{~m}$ at $6.3 \mathrm{ka}$. RSL slightly fell at a rate of $-1.5 \pm 1.9 \mathrm{~m} / \mathrm{ka}$ between 6 and $5 \mathrm{ka}$, remaining relatively stable until $2 \mathrm{ka}$, at which time it fell at a rate of $-0.8 \pm 1.1 \mathrm{~m} / \mathrm{ka}$ to its present value.

\section{Asia}

Investigations of Holocene RSL in the far-field region of Asia are concentrated in southeast Asia [150-153], although studies have expanded in recent years to include South Korea [154], the Philippines [155], China [145 -148], the MalayThai peninsula [160 -164 ], and Japan [165 ]. These records are characterized by a mid-Holocene highstand attributed to hydro-isostatic processes [166, 167 ], which varies in magnitude and timing of initiation. RSL may also be influenced by active subduction zone tectonics from collision of the Eurasian, Indian, Philippine, and Pacific plates [44, 168] or sediment loading from large river deltas [166].

Zong [166] examined China's Yangtze Delta and Taihu area RSL histories and separated regions by geological setting to examine influences of global and local factors. Within large river deltas, RSL did not reach higher than present due to local subsidence and sediment consolidation. Conversely, a highstand of 1 to $2 \mathrm{~m}$ was recorded at Fuijan and East Guangdong where tectonic uplift was observed along the active plate margin of the Eurasian and Philippine plates. In stable coastal sites (e.g., West Guangdong; Fig. 4i), the highstand reaches slightly higher $(<1.4 \mathrm{~m})$ than present-day RSL. In West Guangdong, RSL rose from $-19.6 \pm 1.8 \mathrm{~m}$ at $9.6 \mathrm{ka}$ to its present level at $6.5 \mathrm{ka}$ at rates as high as $7.7 \pm$ $2.2 \mathrm{~m} / \mathrm{ka}$. RSL remained stable from this time to present with a slight fall between $6.5 \mathrm{ka}$ to present at a rate of $-0.2 \pm 0.2 \mathrm{~m} / \mathrm{ka}$ (Figs. 4h, 5e). A recent high-resolution $(\sim \pm 0.1 \mathrm{~m})$ study of corals by $\mathrm{Yu}$ et al. [156], however, indicates mid-Holocene RSL has fluctuated on multi-decadal to century scales likely related to climatic changes.

Holocene studies from the Malay-Thai peninsula suggest a RSL highstand of up to $5 \mathrm{~m}$ between 6 and $4 \mathrm{ka}$, which may have exhibited an oscillatory subsequent fall $[153,160,164$, 169-173 ]. The highstand varies in magnitude by 3 to $4 \mathrm{~m}$ due to spatial variability from hydro-isostasy [167 ]. Bird et al. [160] present sea-level data from the stable location of Singapore, which varies in form from South China (Fig. 4i). High rates of RSL rise $(4.4 \pm 0.5 \mathrm{~m} / \mathrm{ka})$ were observed in the early Holocene between 9 and 6 ka (Fig. 5e) until RSL reached its greatest altitude of $3.3 \pm 0.3 \mathrm{~m}$ at $5.8 \mathrm{ka}$. RSL then fell in the mid Holocene from $6 \mathrm{ka}$ to present at a rate of $-0.4 \pm 0.2 \mathrm{~m} / \mathrm{ka}$.

\section{Oceania}

Their far-field location and relative tectonic stability have made the coastal margins of Australia an important setting 
for studies of deglacial sea-level changes [174-178]. This region is characterized by a mid-Holocene highstand. Both smooth and oscillating sea-level trends have been recorded since the highstand $[179,180]$. This discrepancy in part reflects differences in the sea-level indicators used and their interpretation [178 ].

Woodroffe [181] investigated Holocene sea-level changes from northern Queensland (Fig. 4j). During the Holocene marine transgression, the rate of RSL rise was rapid between 11 and $8 \mathrm{ka}(13 \pm 5 \mathrm{~m} / \mathrm{ka}$; Fig. $5 \mathrm{f})$. RSL reached above present level between 8.0 and $6.2 \mathrm{ka}$ when the average rate of change decreased to $3.0 \pm 2.4 \mathrm{~m} / \mathrm{ka}$. A mid-Holocene highstand at $5.0 \mathrm{ka}$ reached $2.8 \pm 0.4 \mathrm{~m}$ above present level and remained relatively stable until at least $2.3 \mathrm{ka}$. After this time, RSL gradually fell to its present level at a rate of $-0.2 \pm 2.5 \mathrm{~m} / \mathrm{ka}$ between $2 \mathrm{ka}$ and present. Woodroffe [181] did not find any evidence for an oscillatory trend in RSL.

In southeastern Australia, Sloss et al. [182] reviewed the sea-level history for the New South Wales coast. They show RSL rose from $-15 \mathrm{~m}$ between 9.5 and $8 \mathrm{ka}$ at a rate of $8.3 \pm$ $1.6 \mathrm{~m} / \mathrm{ka}$, reaching its present level at $\sim 7 \mathrm{ka}$ and a highstand of $1.4 \pm 0.1 \mathrm{~m}$ at $\sim 5.5 \mathrm{ka}$. While negative and positive fluctuations are observed during the highstand, they are superimposed over a broader RSL fall of $-0.3 \pm 0.2 \mathrm{~m} / \mathrm{ka}$ during this period [182].

In northern New Zealand, Gibb [183] presented RSL data near relatively inactive tectonic regions close to Auckland. Here, RSL rose $25 \mathrm{~m}$ from $9 \mathrm{ka}$ to its present level at $\sim 7 \mathrm{ka}$ and has remained within 1 to $-0.5 \mathrm{~m}$ since [184]. Gehrels et al. [185] suggested that RSL changes from southeastern New Zealand and Tasmania have been close $( \pm 0.5 \mathrm{~m})$ to modern level for the last 6000 years.

\section{Conclusions}

RSL data reveal spatial and temporal changes caused by the varying dominance of eustatic and (glacio- and hydro-) isostatic factors over the Holocene. Near-field regions (e.g., Antarctica, Greenland, Canada, Sweden, and Scotland) are characterized by a complex, spatially variable RSL fall from a maximum marine limit, which reflect the relative influences of eustatic sea-level rise and glacio-isostatic uplift. In intermediate-field regions (e.g., mid-Atlantic and Pacific coasts of the USA, Netherlands, Southern France, St. Croix) isostatic and eustatic effects collectively produced RSL rise. Far-field locations show a characteristic mid-Holocene highstand in RSL, which differs in timing and magnitude across sites from South America, South Africa, Asia, and Oceania.

Acknowledgments This work was supported by National Oceanic and Atmospheric Administration award NA11OAR4310101 (to BPH and WRP) and NSF grants EAR 1402017 (to BPH), EAR 1419366 (to
BPH), OCE 1458904 (to BPH and REK), and ARC 1203415 (to REK). MV contributes to the Labex OT-Med (n ${ }^{\circ}$ ANR-11- LABX-0061) funded by the French Government «Investissements d'Avenir» program of the ANR through the $A^{*}$ MIDEX project ( $n^{\circ}$ ANR-11-IDEX-0001-02). We thank two anonymous reviewers for their insightful comments. This paper is a contribution to PALSEA2. The authors have no conflict of interest or financial interest to report.

\section{References}

1. Lambeck K, Smither C, Johnston P. Sea-level change, glacial rebound and mantle viscosity fornorthern Europe. Geophys J Int. 1998;134:102-44. doi:10.1046/j.1365-246x.1998.00541.x.

2. Engelhart SE, Peltier WR, Horton BP. Holocene relative sea-level changes and glacial isostatic adjustment of the U.S. Atlantic coast. Geology. 2011;39:751-4. doi:10.1130/g31857.1.

3. Milne GA, Peros M. Data-model comparison of Holocene sealevel change in the circum-Caribbean region. Glob Planet Chang. 2013;107:119-31. doi:10.1016/j.gloplacha.2013.04.014.

4. Peltier WR. On eustatic sea level history: Last Glacial Maximum to Holocene. Quat Sci Rev. 2002;21:377-96.

5. Milne GA, Long AJ, Bassett SE. Modelling Holocene relative sealevel observations from the Caribbean and South America. Quat Sci Rev. 2005;24:1183-202. doi:10.1016/J.Quascirev.2004.10. 005.

6. Austermann J, Mitrovica JX, Latychev K, Milne GA. Barbadosbased estimate of ice volume at Last Glacial Maximum affected by subducted plate. Nat Geosci. 2013;6:553-7. doi:10.1038/ ngeo1859.

7. Lambeck K, Rouby H, Purcell A, et al. Sea level and global ice volumes from the Last Glacial Maximum to the Holocene. Proc Natl Acad Sci. 2014;111:15296-303. doi:10.1073/pnas. 1411762111.

8. Kendall RA, Mitrovica JX, Milne GA, et al. The sea-level fingerprint of the 8.2 ka climate event. Geology. 2008;36:423-6. doi:10. 1130/G24550A.1.

9. Mitrovica JX, Gomez N, Clark PU. The Sea-Level Fingerprint of West Antarctic Collapse. Science. 2009;323:753. doi:10.1126/ science. 1166510.

10. Mitrovica JX, Gomez N, Morrow E, et al. On the robustness of predictions of sea level fingerprints. Geophys J Int. 2011;187: 729-42. doi:10.1111/j.1365-246X.2011.05090.x.

11. Gomez N, Mitrovica JX, Tamisiea ME, Clark PU. A new projection of sea level change in response to collapse of marine sectors of the Antarctic Ice Sheet. Geophys J Int. 2010;180:623-34. doi:10. 1111/j.1365-246X.2009.04419.x.

12. Kopp RE, Hay CC, Little CM, X J Mitrovica (this issue). Geogr. Var. Sea-Level Change Curr. Clim. Chang Rep. Doi 10.

13. Milne GA, Gehrels WR, Hughes CW, Tamisiea ME. Identifying the causes of sea-level change. Nat Geosci. 2009;2:471-8. doi:10. 1038/ngeo544.

14. Shennan I, Long AJ, Horton BP (2015) Handbook of Sea-Level Research. John Wiley \& Sons.

15. Fleming K, Johnston P, Zwartz D, et al. Refining the eustatic sealevel curve since the Last Glacial Maximum using far- and intermediate-field sites. Earth Planet Sci Lett. 1998;163:327-42. doi: 10.1016/s0012-821x(98)00198-8.

16. Yokoyama Y, Lambeck K, De Deckker P, et al. Timing of the Last Glacial Maximum from observed sea-level minima. Nature. 2000;406:713-6.

17. Lambeck K, Esat TM, Potter E-K. Links between climate and sea levels for the past three million years. Nature. 2002;419:199-206. doi:10.1038/nature01089. 
18. Clark JA, Farrell WE, Peltier WR. Global changes in postglacial sea level: A numerical calculation. Quat Res. 1978;9:265-87. doi: 10.1016/0033-5894(78)90033-9.

19. Lambeck K, Purcell A, Johnston P, et al. Water-load definition in the glacio-hydro-isostatic sea-level equation. Quat Sci Rev. 2003;22:309-18. doi:10.1016/S0277-3791(02)00142-7.

20. Roy K, Peltier WR. Glacial isostatic adjustment, relative sea level history and mantle viscosity: reconciling relative sea level model predictions for the U.S. East coast with geological constraints. Geophys J Int. 2015;201:1156-81. doi:10.1093/gji/ggv066.

21. Peltier WR, Andrews JT. Glacial-Isostatic Adjustment-I. The Forward Problem. Geophys J R Astron Soc. 1976;46:605-46. doi:10.1111/j.1365-246x.1976.tb01251.x.

22. Wu P, Peltier WR. Glacial isostatic adjustment and the free air gravity anomaly as a constraint on deep mantle viscosity. Geophys J R Astron Soc. 1983;74:377-449.

23. Tushingham AM, Peltier WR. ICE-3G: A new global model of Late Pleistocene deglaciation based upon geophysical predictions of post-glacial relative sea level change. J Geophys Res. 1991;96: 4497. doi:10.1029/90jb01583.

24. Lambeck K. Glacial rebound of the British Isles-II. A high-resolution, high-precision model. Geophys J Int. 1993;115:960-90. doi:10.1111/j.1365-246x.1993.tb01504.x.

25. Mitrovica JX, Peltier WR. A new formalism for inferring mantle viscosity based on estimates of post glacial decay Times: Application to RSL variations in N.E. Hudson Bay. Geophys Res Lett. 1993;20:2183-6. doi:10.1029/93g102136.

26. Mitrovica JX (1996) Haskell [1935] revisited. J Geophys Res 101: 555. doi: 10.1029/95jb03208.

27. Shennan I, Peltier WR, Drummond R, Horton B. Global to local scale parameters determining relative sea-level changes and the post-glacial isostatic adjustment of Great Britain. Quat Sci Rev. 2002;21:397-408.

28. Peltier WR. Global glacial isostasy and the surface of the ice-age earth: The ICE-5G (VM2) model and GRACE. Annu Rev Earth Planet Sci. 2004;32:111-49. doi:10.1146/annurev.earth.32. 082503.144359.

29. Quinlan G, Beaumont C. A comparison of observed and theoretical postglacial relative sea level in Atlantic Canada. Can J Earth Sci. 1981;18:1146-63.

30. Nakada M, Lambeck K. Late Pleistocene and Holocene sea-level change in the Australian region and mantle rheology. Geophys J Int. 1989;96:497-517. doi:10.1111/j.1365-246x.1989.tb06010.x.

31. Peltier WR. Ice Age Paleotopography. Science. 1994;265:195201. doi:10.1126/science.265.5169.195.

32. Lambeck K (2002) Sea level change from mid Holocene to Recent time: An Australian example with global implications. Ice Sheets Sea Level Dyn Earth 33-50. doi: 10.1029/gd029p0033.

33. Lambeck K, Yokoyama Y, Purcell A. Into and out of the Last Glacial Maximum: sea-level change during Oxygen Isotope Stages 3 and 2. Quat Sci Rev. 2002;21:343-60.

34. Lambeck K, Antonioli F, Purcell A, Silenzi S. Sea-level change along the Italian coast for the past 10,000 yr. Quat Sci Rev. 2004;23:1567-98. doi:10.1016/j.quascirev.2004.02.009.

35. Milne GA, Mitrovica JX, Schrag DP. Estimating past continental ice volume from sea-level data. Quat Sci Rev. 2002;21:361-76. doi:10.1016/s0277-3791(01)00108-1.

36. Peltier WR, Fairbanks RG. Global glacial ice volume and Last Glacial Maximum duration from an extended Barbados sea level record. Quat Sci Rev. 2006;25:3322-37. doi:10.1016/j.quascirev. 2006.04.010.

37. Pluet J, Pirazzoli PA (1991) World atlas of Holocene sea-level changes. Elsevier.

38. Mitrovica JX, Milne GA. On the origin of late Holocene sea-level highstands within equatorial ocean basins. Quat Sci Rev. 2002;21: 2179-90. doi:10.1016/S0277-3791(02)00080-X.
39. Milne GA, Mitrovica JX. Searching for eustasy in deglacial sealevel histories. Quat Sci Rev. 2008;27:2292-302. doi:10.1016/j. quascirev.2008.08.018.

40. Engelhart SE, Horton BP, Douglas BC, et al. Spatial variability of late Holocene and 20th century sea-level rise along the Atlantic coast of the United States. Geology. 2009;37:1115-8. doi:10. 1130/G30360A.1.

41. Engelhart S, Horton B, Kemp A. Holocene sea-level changes along the United States' Atlantic coast. Oceanography. 2011;24: 70-9. doi:10.5670/oceanog.2011.28.

42. Compton JS. Holocene sea-level fluctuations inferred from the evolution of depositional environments of the southern Langebaan Lagoon salt marsh, South Africa. The Holocene. 2001;11:395-405. doi:10.1191/095968301678302832.

43. Horton BP, Engelhart SE, Hill DF, et al. Influence of tidal-range change and sediment compaction on Holocene relative sea-level change in New Jersey, USA. J Quat Sci. 2013;28:403-11. doi:10. 1002/jqs.2634.

44. Woodroffe SA, Horton BP. Holocene sea-level changes in the Indo-Pacific. J Asian Earth Sci. 2005;25:29-43. doi:10.1016/j. jseaes.2004.01.009.

45. Horton BP (2007) Sea levels, Late Quaternary: High Latitudes. Encycl Quat Sci 3064-3072.

46. Kemp AC, Horton BP, Engelhart SE (2013) SEA-LEVELS, LATE QUATERNARY | Late Quaternary Relative Sea-Level Changes at Mid-Latitudes. In: Mock SAEJ (ed) Encycl. Quat. Sci. Second Ed. Elsevier, Amsterdam, pp 489-494

47. Dutton A, Carlson AE, Long AJ, et al. (2015) Sea-level rise due to polar ice-sheet mass loss during past warm periods. Science 349: aaa4019. doi:10.1126/science.aaa4019

48. Kopp RE, Horton BP, Kemp AC, Tebaldi C. Past and future sealevel rise along the coast of North Carolina, USA. Clim Chang. 2015;132:693-707. doi:10.1007/s10584-015-1451-x.

49. Engelhart SE, Vacchi M, Horton BP, et al. A sea-level database for the Pacific coast of central North America. Quat Sci Rev. 2015;113:78-92. doi:10.1016/j.quascirev.2014.12.001.

50. Nikitina D, Kemp AC, Engelhart SE, et al. Sea-level change and subsidence in the Delaware Estuary during the last 2200 years. Estuar Coast Shelf Sci. 2015;164:506-19. doi:10.1016/j.ecss. 2015.08.012.

51. Rasmussen C, Williams C. Gaussian processes for machine learning. Cambridge: MIT Press; 2006.

52. McHutchon A, Rasmussen CE (2011) Gaussian Process Training with Input Noise. In: Shawe-Taylor J, Zemel RS, Bartlett PL, et al. (eds) Adv. Neural Inf. Process. Syst. 24. Curran Associates, Inc., pp 1341-1349.

53. Long AJ, Roberts DH, Wright MR. Isolation basin stratigraphy and Holocene relative sea-level change on Arveprinsen Ejland, Disko Bugt, West Greenland. J Quat Sci. 1999;14:323-45.

54. Long AJ, Roberts DH, Rasch M. New observations on the relative sea level and deglacial history of Greenland from Innaarsuit, Disko Bug. Quat Res. 2003;60:162-71. doi:10.1016/S00335894(03)00085-1.

55. Long AJ, Roberts DH, Dawson S. Early Holocene history of the west Greenland Ice Sheet and the GH-8.2 event. Quat Sci Rev. 2006;25:904-22. doi:10.1016/j.quascirev.2005.07.002.

56. Long AJ, Roberts DH. Late Weichselian deglacial history of Disko Bugt, West Greenland, and the dynamics of the Jakobshavns Isbrae ice stream. Boreas. 2003;32:208-26. doi:10. 1111/j.1502-3885.2003.tb01438.x.

57. Bennike O, Björck S, Lambeck K. Estimates of South Greenland late-glacial ice limits from a new relative sea level curve. Earth Planet Sci Lett. 2002;197:171-86. doi:10.1016/S0012-821X(02) 00478-8. 
58. Bennike O, Wagner B, Richter A. Relative sea level changes during the Holocene in the Sisimiut area, south-western Greenland. J Quat Sci. 2011;26:353-61. doi:10.1002/jqs.1458.

59. Woodroffe SA, Long AJ, Lecavalier BS, et al. Using relative sealevel data to constrain the deglacial and Holocene history of southern Greenland. Quat Sci Rev. 2014;92:345-56. doi:10.1016/j. quascirev.2013.09.008.

60. Bennike O, Björck S. Chronology of the last recession of the Greenland Ice Sheet. J Quat Sci. 2002;17:211-9. doi:10.1002/ jqs.670.

61. Sparrenbom CJ, Bennike O, Björck S, Lambeck K. Relative sealevel changes since $15000 \mathrm{cal}$. yr BP in the Nanortalik area, southern Greenland. J Quat Sci. 2006;21:29-48. doi:10.1002/jqs. 940.

62. Sparrenbom CJ, Bennike O, Björck S, Lambeck K. Holocene relative sea-level changes in the Qaqortoq area, southern Greenland. Boreas. 2006;35:171-87. doi:10.1111/j.1502-3885. 2006.tb01148.x.

63. Long AJ. Back to the future: Greenland's contribution to sea-level change. GSA Today. 2009;19:4. doi:10.1130/GSATG40A.1.

64. Long AJ, Woodroffe SA, Roberts DH, Dawson S. Isolation basins, sea-level changes and the Holocene history of the Greenland Ice Sheet. Quat Sci Rev. 2011;30:3748-68. doi:10.1016/j.quascirev. 2011.10.013.

65. Rasch M, Jensen JF. Ancient Eskimo dwelling sites and Holocene relative sea-level changes in southern Disko Bugt, central West Greenland. Polar Res. 1997;16:101-15. doi:10.1111/j.17518369.1997.tb00252.x.

66. Randsalu L (2008) Post Glacial Relative Sea-level Changes in the Tasiusaq Area, Southwest Greenland. Examensarbeten Geol. Vid Lunds Univ. -Kvartär- Geol. Nr 220.

67. Long AJ, Roberts DH, Simpson MJR, et al. Late Weichselian relative sea-level changes and ice sheet history in southeast Greenland. Earth Planet Sci Lett. 2008;272:8-18. doi:10.1016/J. Eps1.2008.03.042.

68. Engelhart SE, Horton BP. Holocene sea level database for the Atlantic coast of the United States. Quat Sci Rev. 2012;54:1225. doi:10.1016/j.quascirev.2011.09.013.

69. Törnqvist TE, Hijma MP. Links between early Holocene ice-sheet decay, sea-level rise and abrupt climate change. Nat Geosci. 2012;5:601-6. doi:10.1038/ngeo1536.

70. Shaw J, Gareau P, Courtney RC. Palaeogeography of Atlantic Canada 13-0 kyr. Quat Sci Rev. 2002;21:1861-78.

71. Kelley JT, Belknap DF, Claesson S. Drowned coastal deposits with associated archaeological remains from a sea-level "slowstand": Northwestern Gulf of Maine, USA. Geology. 2010;38:695-8. doi:10.1130/g31002.1.

72. Hill DF, Griffiths SD, Peltier WR, et al. High-resolution numerical modeling of tides in the western Atlantic, Gulf of Mexico, and Caribbean Sea during the Holocene. J Geophys Res. 2011. doi:10. 1029/2010jc006896.

73. Tornqvist TE, Gonzalez JL, Newsom LA, et al. Deciphering Holocene sea-level history on the US Gulf Coast: A high-resolution record from the Mississippi Delta. Geol Soc Am Bull. 2004;116:1026-39. doi:10.1130/b2525478.1.

74. Hijma MP, Engelhart SE, Törnqvist TE, et al. (2015) A protocol for a geological sea-level database. ShennanHandbook Sea-Level Res 536-553. doi: 10.1002/9781118452547.ch34.

75. Mathews WH, Fyles JG, Nasmith HW. Postglacial crustal movements in southwestern British Columbia and adjacent Washington state. Can J Earth Sci. 1970;7:690-702. doi:10.1139/e70-068.

76. Clague JJ (1980) Late Quaternary Geology and Geochronology of British Columbia. Ministe_re de l'Energie, des Mines et des Ressources.
77. Clague J, Harper JR, Hebda RJ, Howes DE. Late Quaternary sea levels and crustal movements, coastal British Columbia. Can J Earth Sci. 1982;19:597-618. doi:10.1139/e82-048.

78. Eronen M, Kankainen T, Tsukada M. Late Holocene sea-level record in a core from the Puget Lowland, Washington. Quat Res. 1987;27:147-59. doi:10.1016/0033-5894(87)90073-1.

79. Beale H (1991) Relative Rise in Sea-level during the Past 5000 Years at Six Salt Marshes in Northern Puget Sound. Washington.

80. Hutchinson I (1992) Holocene Sea Level Change in the Pacific Northwest: a Cata- logue of Radiocarbon Ages and an Atlas of Regional Sea-level Curves. Occas Pap No 1.:100.

81. Long AJ, Shennan I. Models of rapid relative sea-level change in Washington and Oregon, USA. The Holocene. 1998;8:129-42.

82. Clague JJ, James TS. History and isostatic effects of the last ice sheet in southern British Columbia. Quat Sci Rev. 2002;21:71-87. doi:10.1016/s0277-3791(01)00070-1.

83. Hutchinson I, James TS, Clague JJ, et al. Reconstruc- tion of late Quaternary sea-level change in southwestern British Columbia from sediments in isolation basins. Boreas. 2004;33:183-94.

84. James TS, Hutchinson I, Vaughn Barrie J, et al. Relative Sea-Level Change in the Northern Strait of Georgia, British Columbia. Géog Phys Quatern. 2005;59:113. doi:10.7202/014750ar.

85. James TS, Gowan EJ, Wada I, Wang K. Viscosity of the asthenosphere from glacial isostatic adjustment and subduction dynamics at the northern Cascadia subduction zone, British Columbia, Canada. J Geophys Res Solid Earth. 2009;114:B04405. doi:10. 1029/2008JB006077.

86. Atwater BF. Geologic evidence for earthquakes during the past 2000 years along the Copalis River, southern coastal Washington. J Geophys Res. 1992;97:1901-19. doi:10.1029/ 91jb02346.

87. Darienzo ME, Peterson CD, Clough C. Stratigraphic evidence for great subduction-zone earthquakes at four estuaries in Northern Oregon. U J Coast Res. 1994;10:850-76.

88. Clague JJ, Bobrowsky PT. Tsunami deposits beneath tidal marshes on Vancouver Island. Br Columbia Geol Soc Am Bull. 1994;106:1293-303.

89. Nelson AR, Jennings AE, Kashima K. An earthquake history derived from stratigraphic and microfossil evidence of relative sea-level change at Coos Bay, southern coastal Oregon. Geol Soc Am Bull. 1996;108:141-54. doi:10.1130/0016-7606(1996) $108<0141$ :aehdfs $>2.3$.co;2.

90. Atwater BF, Hemphill-Haley E (1997) Recurrence Intervals for Great Earthquakes of the Past 3, 500 Years at Northeastern Willapa Bay. Wash U Geol Surv Prof Pap 1576:119.

91. Witter RC, Kelsey HM, Hemphill-Haley E. Great Cascadia earthquakes and tsunamis of the past 6700 years, Coquille River estuary, southern coastal Oregon. Geol Soc Am Bull. 2003;115:1289. doi:10.1130/b25189.1.

92. Hawkes AD, Horton BP, Nelson AR, et al. Coastal subsidence in Oregon, USA, during the giant Cascadia earthquake of AD 1700. Quat Sci Rev. 2011;30:364-76. doi:10.1016/J.Quascirev.2010.11. 017.

93. Peterson CD, Carver GA, Cruikshank KM, et al. Evaluation of the use of paleotsunami deposits to reconstruct inundation distance and runup heights associated with prehistoric inundation events, Crescent City, southern Cascadia margin. Earth Surf Process Landf. 2011;36:967-80. doi:10.1002/esp.2126.

94. Shugar DH, Walker IJ, Lian OB, et al. Post-glacial sea-level change along the Pacific coast of North America. Quat Sci Rev. 2014;97:170-92. doi:10.1016/j.quascirev.2014.05.022.

95. Shennan I, Horton B. Holocene land- and sea-level changes in Great Britain. J Quat Sci. 2002;17:511-26. doi:10.1002/jqs.710.

96. Vink A, Steffen H, Reinhardt L, Kaufmann G. Holocene relative sea-level change, isostatic subsidence and the radial viscosity structure of the mantle of northwest Europe (Belgium, the 
Netherlands, Germany, southern North Sea). Quat Sci Rev. 2007;26:3249-75. doi:10.1016/j.quascirev.2007.07.014.

97. Fairbanks RG. A 17,000-Year Glacio-Eustatic Sea-Level Record Influence of Glacial Melting Rates on the Younger Dryas Event and Deep-Ocean Circulation. Nature. 1989;342:637-42.

98. Rostami K, Peltier WR, Mangini A. Quaternary marine terraces, sea-level changes and uplift history of Patagonia, Argentina: comparisons with predictions of the ICE-4G (VM2) model of the global process of glacial isostatic adjustment. Quat Sci Rev. 2000;19:1495-525. doi:10.1016/S0277-3791(00)00075-5.

99. Toscano MA, Peltier WR, Drummond R. ICE-5G and ICE-6G models of postglacial relative sea-level history applied to the Holocene coral reef record of northeastern St Croix, U.S.V.I.: investigating the influence of rotational feedback on GIA processes at tropical latitudes. Quat Sci Rev. 2011;30:3032-42. doi:10.1016/ j.quascirev.2011.07.018.

100. Roeleveld W, Loon AJV. The Holocene development of the Young Coastal Plain of Suriname. Geol En Mijnb. 1979;58:21-8.

101. Bezerra FHR, Barreto AMF, Suguio K. Holocene sea-level history on the Rio Grande do Norte State coast, Brazil. Mar Geol. 2003;196:73-89. doi:10.1016/S0025-3227(03)00044-6.

102. Boski T, Bezerra FHR, de Fátima PL, et al. Sea-level rise since 8.2 ka recorded in the sediments of the Potengi-Jundiai Estuary, NE Brasil. Mar Geol. 2015;365:1-13. doi:10.1016/j.margeo.2015.04. 003.

103. Angulo RJ, Lessa GC, de Souza MC. A critical review of mid- to late-Holocene sea-level fluctuations on the eastern Brazilian coastline. Quat Sci Rev. 2006;25:486-506. doi:10.1016/j.quascirev. 2005.03.008.

104. Porter SC, Stuiver M, Heusser CJ. Holocene sea-level changes along the Strait of Magellan and Beagle Channel, southernmost South America. Quat Res. 1984;22:59-67. doi:10.1016/00335894(84)90006-1.

105. Rabassa J, Coronato A, Bujalesky G, et al. Quaternary of Tierra del Fuego, Southernmost South America: an updated review. Quat Int. 2000;68-71:217-40. doi:10.1016/s1040-6182(00)00046-x.

106. Nakada M, Kimura R, Okuno J, et al. Late Pleistocene and Holocene melting history of the Antarctic ice sheet derived from sea-level variations. Mar Geol. 2000;167:85-103. doi:10.1016/ s0025-3227(00)00018-9.

107. Bassett SE, Milne GA, Bentley MJ, Huybrechts P. Modelling Antarctic sea-level data to explore the possibility of a dominant Antarctic contribution to meltwater pulse IA. Quat Sci Rev. 2007;26:2113-27. doi:10.1016/j.quascirev.2007.06.011.

108. Whitehouse PL, Bentley MJ, Le Brocq AM. A deglacial model for Antarctica: geological constraints and glaciological modelling as a basis for a new model of Antarctic glacial isostatic adjustment. Quat Sci Rev. 2012;32:1-24. doi:10.1016/j.quascirev.2011.11. 016.

109. Argus DF, Peltier WR, Drummond R, Moore AW. The Antarctica component of postglacial rebound model ICE-6G_C (VM5a) based on GPS positioning, exposure age dating of ice thicknesses, and relative sea level histories. Geophys J Int. 2014;198:537-63. doi:10.1093/gji/ggu140.

110. Bentley MJ, Hodgson DA, Smith JA, Cox NJ. Relative sea level curves for the South Shetland Islands and Marguerite Bay, Antarctic Peninsula. Quat Sci Rev. 2005;24:1203-16. doi:10. 1016/j.quascirev.2004.10.004.

111. Bentley MJ, Johnson JS, Hodgson DA, et al. Rapid deglaciation of Marguerite Bay, western Antarctic Peninsula in the Early Holocene. Quat Sci Rev. 2011;30:3338-49. doi:10.1016/j. quascirev.2011.09.002.

112. Watcham EP, Bentley MJ, Hodgson DA, et al. A new Holocene relative sea level curve for the South Shetland Islands, Antarctica. Quat Sci Rev. 2011;30:3152-70. doi:10.1016/j.quascirev.2011.07. 021.
113. Berkman PA, Andrews JT, Björck S, et al. Circum-Antarctic coastal environmental shifts during the Late Quaternary reflected by emerged marine deposits. Antarct Sci. 1998. doi:10.1017/ s0954102098000406.

114. Simms AR, DeWitt R, Kouremenos P, Drewry AM. A new approach to reconstructing sea levels in Antarctica using optically stimulated luminescence of cobble surfaces. Quat Geochronol. 2011;6:50-60. doi:10.1016/j.quageo.2010.06.004.

115. Simms AR, Ivins ER, DeWitt R, et al. Timing of the most recent Neoglacial advance and retreat in the South Shetland Islands, Antarctic Peninsula: insights from raised beaches and Holocene uplift rates. Quat Sci Rev. 2012;47:41-55. doi:10.1016/j. quascirev.2012.05.013.

116. Tooley MJ. Sea-Level Changes during the Last 9000 Years in North-West England. Geogr J. 1974;140:18. doi:10.2307/ 1797005.

117. Devoy RJN. Flandrian Sea-Level Changes and Vegetational History of the Lower Thames Estuary. Philos Trans R Soc Lond Ser B Biol Sci. 1979;285:355.

118. Van de Plassche O. Sea-level change and water movements in the Netherlands during the Holocene. Meded Rijks Geol Dienst. 1982;36:1-93.

119. Shennan I. Holocene crustal movements and sea-level changes in Great Britain. J Quat Sci. 1989;4:77-89. doi:10.1002/jqs. 3390040109.

120. Denys L, Baeteman C. Holocene evolution of relative sea level and local mean high water spring tides in Belgium - a first assessment. Mar Geol. 1995;124:1-19. doi:10.1016/0025-3227(95) 00029-x.

121. Shennan I, Lambeck K, Horton B, et al. Late Devensian and Holocene records of relative sea-level changes in northwest Scotland and their implications for glacio-hydro-isostatic modelling. Quat Sci Rev. 2000;19:1103-35. doi:10.1016/S02773791(99)00089-X.

122. Yu S-Y, Berglund BE, Sandgren P, Lambeck K. Evidence for a rapid sea-level rise 7600 yr ago. Geology. 2007;35:891-4. doi:10. 1130/G23859A.1.

123. Hijma MP, Cohen KM. Timing and magnitude of the sea-level jump preluding the $8200 \mathrm{yr}$ event. Geology. 2010;38:275-8. doi: 10.1130/G30439.1.

124. Flemming NC. Archaeological evidence for eustatic change of sea level and earth movements in the western Mediterranean during the last 2,000 years. Geol Soc Am Spec Pap. 1969;109:1-98.

125. Pirazzoli PA. Sea level variations in the northwest Mediterranean during Roman times. Science. 1976;194:519-21.

126. Morhange C, Pirazzoli PA, Marriner N, et al. Late Holocene relative sea-level changes in Lebanon, Eastern Mediterranean. Mar Geol. 2006;230:99-114. doi:10.1016/j.margeo.2006.04.003.

127. Vött A. Relative sea level changes and regional tectonic evolution of seven coastal areas in NW Greece since the mid-Holocene. Quat Sci Rev. 2007;26:894-919. doi:10.1016/j.quascirev.2007. 01.004 .

128. Vacchi M, Rovere A, Chatzipetros A, et al. An updated database of Holocene relative sea level changes in NE Aegean Sea. Quat Int. 2014;328-329:301-10. doi:10.1016/j.quaint.2013.08.036.

129. Lambeck K, Bard E. Sea-level change along the French Mediterranean coast for the past 30000 years. Earth Planet Sci Lett. 2000;175:203-22. doi:10.1016/s0012-821x(99)00289-7.

130. Lambeck K, Anzidei M, Antonioli F, et al. Sea level in Roman time in the Central Mediterranean and implications for recent change. Earth Planet Sci Lett. 2004;224:563-75. doi:10.1016/j. eps1.2004.05.031.

131. Antonioli F, Ferranti L, Fontana A, et al. Holocene relative sealevel changes and vertical movements along the Italian and Istrian coastlines. Quat Int. 2009;206:102-33. doi:10.1016/j.quaint.2008. 11.008 . 
132. Faccenna C, Becker TW, Auer L, et al. Mantle dynamics in the Mediterranean. Rev Geophys. 2014;52:283-332. doi:10.1002/ $2013 \mathrm{rg} 000444$.

133. Evelpidou N, Karkani A, Pirazzoli PA. Fossil shorelines at Corfu and surrounding islands deduced from erosional notches. The Holocene. 2014;24:1565-72. doi:10.1177/0959683614544057.

134. Pirazzoli PA, Thommeret J, Thommeret Y, et al. Crustal block movements from holocene shorelines: Crete and antikythira (Greece). Tectonophysics. 1982;86:27-43. doi:10.1016/00401951(82)90060-9.

135. Anthony EJ, Marriner N, Morhange C. Human influence and the changing geomorphology of Mediterranean deltas and coasts over the last 6000years: From progradation to destruction phase? EarthSci Rev. 2014;139:336-61.

136. Stanley DJ, McRea JE, Waldron JC (1996) Nile Delta drill core and sample database for 1985-1994: Mediterranean Basin (MEDIBA) Program. Smithson Contrib Mar Sci 1-428. doi: 10.5479/si.01960768.37.1.

137. Flaux C, Claude C, Marriner N, Morhange C. A 7500-year strontium isotope record from the northwestern Nile delta (Maryut lagoon, Egypt). Quat Sci Rev. 2013;78:22-33. doi:10.1016/j. quascirev.2013.06.018.

138. Vacchi M, Marriner N, Morhange C, et al. Multiproxy assessment of Holocene relative sea- level changes in the western Mediterranean: sea-level variability improvements in the definition of the isostatic signal. Under review.

139. Morhange C, Pirazzoli PA. Mid-Holocene emergence of southern Tunisian coasts. Mar Geol. 2005;220:205-13. doi:10.1016/j. margeo.2005.06.031.

140. Mauz B, Ruggieri G, Spada G. Terminal Antarctic melting inferred from a far-field coastal site. Quat Sci Rev. 2015;116:12232. doi:10.1016/j.quascirev.2015.03.008.

141. Marriner N, Flaux C, Morhange C, Kaniewski D. Nile Delta's sinking past: Quantifiable links with Holocene compaction and climate-driven changes in sediment supply? Geology. 2012;40: 1083-6. doi:10.1130/g33209.1.

142. Jaritz W, Ruder J, Schlenker B. Das Quartär im Küstengebiet von Mozambique und seine Schwermineralführung. Geol Jahrb. 1977;26:3-93.

143. Ramsay PJ, Cooper JAG. Late Quaternary Sea-Level Change in South Africa. Quat Res. 2002;57:82-90. doi:10.1006/qres.2001. 2290.

144. Norström E, Risberg J, Gröndahl H, et al. Coastal paleo-environment and sea-level change at Macassa Bay, southern Mozambique, since c 6600 cal BP. Quat Int. 2012;260:153-63. doi:10.1016/j.quaint.2011.11.032.

145. Woodroffe SA, Long AJ, Punwong P, et al. (2015) Radiocarbon dating of mangrove sediments to constrain Holocene relative sealevel change on Zanzibar in the southwest Indian Ocean. The Holocene 0959683615571422. doi: 10.1177/0959683615571422.

146. Colonna M, Casanova J, Dullo W-C, Camoin G. Sea-Level Changes and 8180 Record for the Past 34,000 yr from Mayotte Reef, Indian Ocean. Quat Res. 1996;46:335-9. doi:10.1006/qres. 1996.0071.

147. Camoin GF, Colonna M, Montaggioni LF, et al. Holocene sea level changes and reef development in the southwestern Indian Ocean. Coral Reefs. 1997;16:247-59. doi:10.1007/ s003380050080.

148. Woodroffe SA, Long AJ, Milne GA, et al. New constraints on late Holocene eustatic sea-level changes from Mahé, Seychelles. Quat Sci Rev. 2015;115:1-16. doi:10.1016/j.quascirev.2015.02.011.

149. Ramsay PJ. 9000 Years of sea-level change along the southern African coastline. Quat Int. 1996;31:71-5. doi:10.1016/10406182(95)00040-P.

150. Geyh MA, Kudrass H-R (1979) Sea-level changes during the late Pleistocene and Holocene in the Strait of Malacca.
151. Chappell J, Polach H. Postglacial Sea-Level Rise from a Coral Record at Huon Peninsula, Papua-New-Guinea. Nature. 1991;349:147-9.

152. Woodroffe C, McLean R. Microatolls and recent sea level change on coral atolls. Nature. 1990;344:531-4. doi:10.1038/344531a0.

153. Scoffin TP, Tissier MDAL. Late Holocene sea level and reef-flat progradation, Phuket, South Thailand. Coral Reefs. 1998;17:2736. doi:10.1007/s003380050128.

154. Munyikwa K, Choi JH, Choi KH, et al. Coastal Dune Luminescence Chronologies Indicating a Mid-Holocene Highstand along the East Coast of the Yellow Sea. J Coast Res. 2008;2:92-103. doi:10.2112/05-0570.1.

155. Shen C-C, Siringan FP, Lin K, et al. Sea-level rise and coral-reef development of Northwestern Luzon since $9.9 \mathrm{ka}$. Palaeogeogr Palaeoclimatol Palaeoecol. 2010;292:465-73. doi:10.1016/j. palaeo.2010.04.007.

156. Yu K-F, Zhao J-X, Done T, Chen T-G. Microatoll record for large century-scale sea-level fluctuations in the mid-Holocene. Quat Res. 2009;71:354-60. doi:10.1016/j.yqres.2009.02.003.

157. Wang Z, Zhuang C, Saito Y, et al. Early mid-Holocene sea-level change and coastal environmental response on the southern Yangtze delta plain, China: implications for the rise of Neolithic culture. Quat Sci Rev. 2012;35:51-62. doi:10.1016/j.quascirev. 2012.01.005

158. Wang Z, Zhan Q, Long H, et al. Early to mid-Holocene rapid sealevel rise and coastal response on the southern Yangtze delta plain, China. J Quat Sci. 2013;28:659-72. doi:10.1002/jqs.2662.

159. Wang F, Li J, Chen Y, et al. The record of mid-Holocene maximum landward marine transgression in the west coast of Bohai Bay, China. Mar Geol. 2015;359:89-95. doi:10.1016/j.margeo. 2014.11.013.

160. Bird MI, Austin WEN, Wurster CM, et al. Punctuated eustatic sealevel rise in the early mid-Holocene. Geology. 2010;38:803-6. doi:10.1130/G31066.1.

161. Hanebuth TJJ, Voris HK, Yokoyama Y, et al. Formation and fate of sedimentary depocentres on Southeast Asia's Sunda Shelf over the past sea-level cycle and biogeographic implications. Earth-Sci Rev. 2011;104:92-110. doi:10.1016/j.earscirev.2010.09.006.

162. Scheffers A, Brill D, Kelletat D, et al. Holocene sea levels along the Andaman Sea coast of Thailand. The Holocene. 2012;22: 1169-80. doi:10.1177/0959683612441803.

163. Stattegger K, Tjallingii R, Saito Y, et al. Mid to late Holocene sealevel reconstruction of Southeast Vietnam using beachrock and beach-ridge deposits. Glob Planet Chang. 2013;110:214-22. doi: 10.1016/j.gloplacha.2013.08.014.

164. Parham PR, Saito Y, Sapon N, et al. Evidence for ca. 7-ka maximum Holocene transgression on the Peninsular Malaysia east coast. J Quat Sci. 2014;29:414-22. doi:10.1002/jqs.2714.

165. Tanigawa K, Hyodo M, Sato H. Holocene relative sea-level change and rate of sea-level rise from coastal deposits in the Toyooka Basin, western Japan. The Holocene. 2013;23:103951. doi:10.1177/0959683613479680.

166. Zong Y. Mid-Holocene sea-level highstand along the Southeast Coast of China. Quat Int. 2004;117:55-67. doi:10.1016/S10406182(03)00116-2.

167. Horton BP, Gibbard PL, Mine GM, et al. Holocene sea levels and palaeoenvironments, Malay-Thai Peninsula, southeast Asia. The Holocene. 2005;15:1199-213. doi:10.1191/0959683605h1891rp.

168. Yao Y, Zhan W, Sun J, Sun J. Emerged fossil corals on the coast of northwestern Hainan Island, China: Implications for midHolocene sea level change and tectonic uplift. Chin Sci Bull. 2013;58:2869-76. doi:10.1007/s11434-013-5692-7.

169. Tija HD. Sea-level changes in the tectonically stable Malay-Thai Peninsula. Quat Int. 1996;31:95-101. 
170. Geyh MA, Streif H, Kudrass H-R. Sea-level changes during the late Pleistocene and Holocene in the Strait of Malacca. Nature. 1979;278:441-3. doi:10.1038/278441a0.

171. Hesp PA, Hung CC, Hilton M, et al. A first tentative Holocene sealevel curve for Singapore. J Coast Res. 1998;14:308-14.

172. Kamaludin, BH Mid-Holocene to recent sea level changes in Peninsular Malaysia: a tectonic implication. Geol Soc Malays Bull 46:313-318.

173. Bird MI, Fifield LK, Teh TS, et al. An inflection in the rate of early mid-Holocene eustatic sea-level rise: A new sea-level curve from Singapore. Estuar Coast Shelf Sci. 2007;71:523-36. doi:10.1016/ j.ecss.2006.07.004.

174. Fairbridge RW. Eustatic changes in sea level. Phys Chem Earth. 1961;4:99-185. doi:10.1016/0079-1946(61)90004-0.

175. Hopley D. Sea Level Change on the Great Barrier Reef: An Introduction. Philos Trans R Soc Math Phys Eng Sci. 1978;291: 159-66. doi:10.1098/rsta.1978.0096.

176. Yokoyama Y, Purcell A, Marshall JF, Lambeck K. Sea-level during the early deglaciation period in the Great Barrier Reef, Australia. Glob Planet Chang. 2006;53:147-53. doi:10.1016/j. gloplacha.2006.01.014.

177. Woodroffe CD, McGregor HV, Lambeck K, et al. Mid-Pacific microatolls record sea-level stability over the past $5000 \mathrm{yr}$. Geology. 2012;40:951-4. doi:10.1130/G33344.1.
178. Lewis SE, Sloss CR, Murray-Wallace CV, et al. Post-glacial sealevel changes around the Australian margin: a review. Quat Sci Rev. 2013;74:115-38. doi:10.1016/j.quascirev.2012.09.006.

179. Baker RGV, Haworth RJ. Smooth or oscillating late Holocene sealevel curve? Evidence from the palaeo-zoology of fixed biological indicators in east Australia and beyond. Mar Geol. 2000;163:36786. doi:10.1016/S0025-3227(99)00118-8.

180. Sloss CR, Murray-Wallace CV, Jones BG. Holocene sea-level change on the southeast coast of Australia: a review. The Holocene. 2007;17:999-1014. doi:10.1177/0959683607082415.

181. Woodroffe SA. Testing models of mid to late Holocene sea-level change, North Queensland, Australia. Quat Sci Rev. 2009;28: 2474-88. doi:10.1016/j.quascirev.2009.05.004.

182. Sloss CR, Murray-Wallace CV, Jones BG (2007) Holocene sea-level change on the southeast coast of Australia: a review. The Holocene.

183. Gibb JG. A New Zealand regional Holocene eustatic sea-level curve and its application to determination of vertical tectonic movements. R Soc N Z Bull. 1986;24:377-95.

184. Hayward BW, Grenfell HR, Sandiford A, et al. Foraminiferal and molluscan evidence for the Holocene marine history of two breached maar lakes, Auckland, New Zealand. N Z J Geol Geophys. 2002;45:467-79. doi:10.1080/00288306.2002.9514986.

185. Gehrels WR, Callard SL, Moss PT, et al. Nineteenth and twentieth century sea-level changes in Tasmania and New Zealand. Earth Planet Sci Lett. 2012;315-316:94-102. doi:10.1016/j.epsl.2011.08.046. 